\title{
PENGARUH DANA TRANSFER DANA DESA DAN PAD TERHADAP INDEKS PEMBANGUNAN MANUSIA DI PROVINSI JAWA BARAT
}

\author{
Otong Suhyanto \\ otong.suhyanto@uinjkt.ac.id \\ Fakultas Ilmu Tarbiyah dan Keguruan UIN Syarif Hidayatullah Jakarta \\ Bambang Juanda \\ Akhmad Fauzi \\ Fakultas Ekonomi dan Manajeman Institut Pertanian Bogor \\ Ernan Rustiadi \\ Fakultas Pertanian Institut Pertanian Bogori
}

\begin{abstract}
The Human Development Index or HDI can describe the quality of human resources in an area. The IPM states how a group of community members can access development outcomes in education, decent living standards, and health. The West Java HDI score in general always shows an upward trend from year to year, but the score is always below the national average. This study aims to analyze the effect of regional income in the form of transfer funds (DAU, DBH, and DAK), Village Funds, and PAD on the human development index or HDI, and the regional income has the highest total effect on HDI. The method used is a regression analysis of panel data model fixed effects. Based on the results of the analysis, it knowns that all transfer funds affect the increase in HDI, as well as local revenue and village funds. Regional revenues that have the most significant total influence on HDI are, respectively, DAU, PAD, and DAK. Local governments must spend transfer funds, PAD, and Village Funds for productive activities.
\end{abstract}

Key words: HDI; fund transfer; panel data; fixed effect model

\section{ABSTRAK}

Indeks Pembangunan Manusia atau IPM bisa mengambarkan kualitas sumberdaya manusia di suatu daerah. IPM menyatakan bagaimana sekelompok anggota masyarakat dapat mengakses hasil pembangunan berupa pendidikan, standar hidup layak, dan kesehatan. Skor IPM Jawa Barat secara umum selalu memperlihatkan tren naik dari tahun ke tahun, tetapi skornya selalu di bawah dari ratarata nasional. Penelitian ini bertujuan untuk manganalisis pengaruh pendapatan daerah berupa dana transfer (DAU, DBH dan DAK), Dana Desa dan PAD terhadap indeks pembangunan manusia atau IPM, dan menganalisis pendapatan daerah yang pengaruh totalnya paling tinggi terhadap IPM. Metode yang digunakan berupa analisis regresi data panel model fixed effect. Berdasarkan hasil analisis sudah diketahui bahwa semua dana transfer berpengaruh terhadap peningkatan IPM, begitu juga dengan pendapatan asli daerah dan dana desa. Pendapatan daerah yang pengaruh totalnya paling besar terhadap IPM secara berurutan adalah DAU, PAD, dan DAK. Pemerintah daerah harus membelanjakan dana transfer, PAD dan Dana Desa untuk kegiatan produktif.

Kata kunci: IPM; dana transfer; data panel; fixed effect model

\section{PENDAHULUAN}

Indeks Pembangunan Manusia (IPM) atau Human Development Index (HDI) menjelaskan bagaimana selompok penduduk di suatu daerah dapat mengakses hasil pembangunan berupa standar hidup layak, kesehatan, dan pendidikan. Ketiga indikator tersebut sangat penting karena bisa menggambarkan kualitas hidup suatu masyarakat yang mendiami wilayah tersebut. Skor IPM berkaitan erat dengan kodisi SDM suatu wilayah, makin tinggi skornya berarti SDM wilayah tersebut berkualitas, sebaliknya kalau skornya rendah, rendah pula kualitas 
SDM di wilayah tersebut. Padahal SDM merupakan faktor utama, bukan yang lainnya, maju dan mundurnya suatu negara atau daerah (Todaro, 2000).

Skor IPM provinsi-provinsi yang ada di Pulau Jawa, secara umum selalu memperlihatkan tren meningkat secara linier. DKI Jakarta dan DI Yogyakarta merupakan daerah dengan IPM yang relatif tinggi dibandingkan IPM Nasional, sedangkan Jawa Tengah, Jawa Timur, Jawa Barat dan Banten skor IPM-nya tidak terlalu berbeda dibanding IPM nasional, tetapi jika diselidiki lebih jauh, skor IPM Provinsi Jawa barat masih di bawah skor IPM nasional. Berdasarkan hal tersebut berati IPM Jawa Barat belum menunjukkan hasil yang menggembirakan karena tidak lebih baik dibandingkan rata-rata nasional.

Meningkatkan skor IPM bagi Pemprov Jawa Barat, bukan perkara yang mudah. Bahkan saking susahnya meningkatkan skor IPM, yang awalnya memproyeksikan pencapaian IPM 80 poin akan tercapai pada tahun 2015, kemudian dirubah menjadi tahun 2022 sesuai dengan Perda No.24 Tahun 2010 tentang perubahan Perda No. 9 Tahun 2008 tentang Rencana Pembangunan Jangka Panjang Daerah (RPJPD) Tahun 2005-2025 dan Perda No 25 Tahun 2013 tentang Rencana Pembangunan Jangka Menengah Daerah (RPJMD) Tahun 20132018 (Dinkes Jabar, 2016).

Transfer ke daerah dan dana desa yang selanjutnya disingkat TKDD adalah bagian dari Belanja Negara yang dialokasikan dalam Anggaran Pendapatan dan Belanja Negara kepada daerah dan desa dalam rangka mendanai pelaksanaan urusan yang telah diserahkan kepada pemerintah daerah dan desa (PMK, 2017). Pelaksanaan transfer ke daerah dari pemerintah yang tingkatnya lebih tinggi ke pemerintahan yang tingkatnya lebih rendah merupakan konsekwensi diberlakukannya otonomi daerah. Penyerahan sebagian tanggung jawab dari pemerintah pusat ke daerah tentu harus diiringi dengan pendanaan atau sering disebut desentralisasi fiskal.
Pelaksanaan otonomi daerah di Indonesia hampir be`rusia dua dasawarsa. Pelaksanaan otonomi telah banyak membawa perubahan yang signifikan terhadap sistem pemerintahan. Sejak 1999 hingga 2014 ada 223 daerah otonom baru atau DOB yang terbentuk, jumlah itu terdiri dari 8 provinsi, 181 kabupaten, dan 34 kota, sehingga saat ini ada 34 provinsi, 415 kabupaten, dan 93 kota. Desentralisasi fiskal dan administrasi telah meningkatkan responsivitas pemerintah daerah terhadap penyediaan infrastruktur publik, investasi kabupaten atau kota, infrastruktur publik mulai menunjukkan pola pendorong ke arah konvergensi (KisKatos dan Sjahrir, 2017). Tetapi di sisi lain redistribusi dana transfer dari Jawa-Bali ke luar Jawa-Bali hanya berpengaruh sedikit terhadap peranan ekonomi wilayah di luar Jawa-Bali. Wilayah Jawa-Bali masih menjadi pusat perekonomian, dengan kata lain, kebijakan desentralisasi fiskal hanya sedikit mengurangi ketimpangan wilayah di Indonesia (Juanda et al., 2017).

Pemerintah telah menggelontorkan dana yang cukup besar untuk sektor pendidikan dan kesehatan, dimana keduanya merupakan komponen IPM. Sesuai dengan mandat UUD 1945 hasil revisi yang mengamanatkan minimal $20 \%$ dan $5 \%$ dari APBN untuk kedua sektor tersebut. APBD juga harus dialokasikan untuk sektor pendidikan dan kesehatan dengan komposisi yang sama, ini artinya lebih dari seperempat anggaran pusat dan daerah dialokasikan untuk meningkatkan IPM. Namun demikian skor IPM Indonesia hanya 70.70 berada diurutan ke 111 dari 189 negara (UNDP, 2019). Bahkan menurut (Brojonegoro, 2019) alokasi belanja pendidikan yang sukup besar yaitu $20 \%$ dari APBD ternyata belum berdampak pada pertumbuhan jasa pendidikan, serta posisi Indonesia berdasarkan hasil Skor PISA tidak menggembirakan.

Berdasarkan uraian di atas, penelitian ini bertujuan untuk menganalisis pengaruh dana transfer, dana desa dan Pendapatan Asli Daerah atau PAD terhadap Indeks 
Pembangunan Manusia atau IPM di Provisi Jawa Barat; mengetahui dana trasfer yang paling besar pengaruhnya terhadap IPM.

\section{TINJAUAN TEORETIS \\ Dana Transfer}

Menurut Musgrave (1969), pemerintah dalam perekonomian menjalankan fungsi alokasi, distribusi dan stabilisasi dalam rangka mendorong pertumbuhan dan pemerataan kesejateraan. Fungsi alokasi merupakan argumen diberlakukannya desentralisasi fiskal yang berjalan selama ini. Desentralisasi adalah transfer kewenangan serta tanggung jawab fungsi publik dari pemerintah pusat kepada pemerintah di bawahnya (Litvack dan Seddon 1999). Menurut Oates (1999), kewenangan belanja daerah merupakan implikasi kebijakan desentralisasi. Desentralisasi fiskal merupakan pemberian kewenangan kepada daerah untuk menggali sumber-sumber pendapatan, hak untuk menerima transfer dari pemerintahan yang lebih tinggi, dalam menentukan belanja rutin maupun investasi. Dengan adanya desentralisasi, maka sebagian kewenangan yang sebelumnya menjadi tanggung jawab pusat didelegasikan ke daerah. Pendelegasian kewenangan ini harus diikuti dengan pemberian sumber pendanaan karena proses peralihan tanggung jawab tersebut. Pemberian dana ini tetap harus dilaporkan kepada pemberi dana sebagai bentuk pertanggungjawaban. Titik berat desentralisasi fiskal adalah desentralisasi pada sisi belanja, pendanaan ini sebagian besar bersifat block grant, sehingga terdapat diskresi untuk membelanjakannya.

Transfer atau hibah antar pemerintah dapat diklasifikasikan ke dalam dua kategori: transfer tanpa syarat (unconditional), dan transfer bersyarat (conditional) (Shah, 2007). Transfer tujuan umum atau generalpurpose transfers disediakan sebagai dukungan anggaran umum, tanpa ikatan, dan biasanya diamanatkan dalam undangundang, walau terkadang bersifat ad hoc. Transfer ini bertujuan untuk menjaga otonomi pemerintahan lokal dan meningkat- kan keadilan antar-yurisdiksi. Ketentuan hibah tidak akan menghilangkan kebebasan otoritas lokal untuk melaksanakan kebijakan dalam yurisdiksi mereka sendiri.

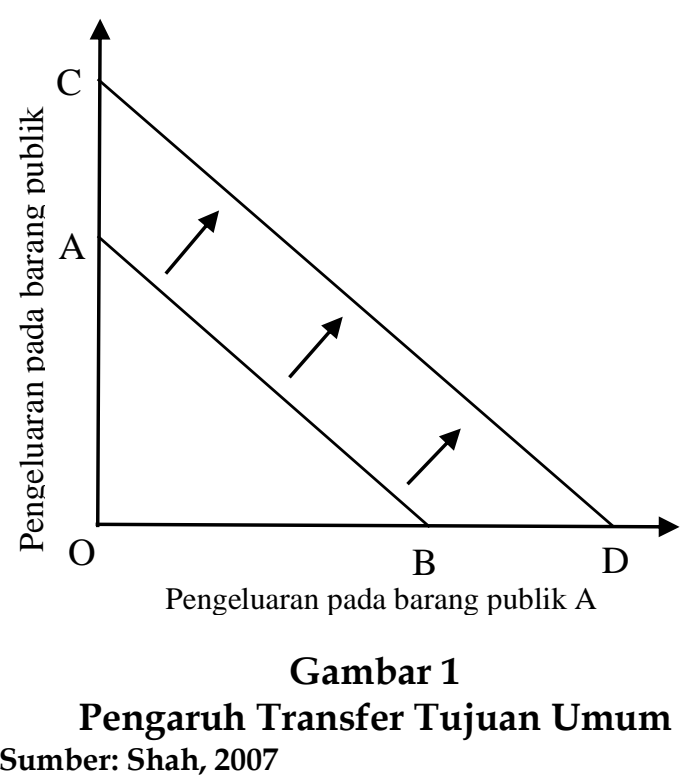

Transfer tujuan umum memiliki efek pendapatan, seperti dalam Gambar 1 ditunjukkan oleh pergeseran garis anggaran daerah penerima (garis $A B$ ) ke atas dan ke kanan dengan $A C=B D$, sehingga diperoleh garis anggaran baru $C D$. Transfer tujuan umum berbasis formula sangat umum berlaku di berbagai negara. Beberapa bukti menunjukkan bahwa transfer tujuan umum mendorong pemerintah kota untuk kurang memanfaatkan basis pajak mereka sendiri (Shah, 1991).

Transfer tujuan khusus atau specificpurpose transfers dimaksudkan untuk memberikan insentif bagi pemerintah daerah untuk melakukan program atau kegiatan tertentu yang sesuai dengan program pusat. Hibah ini dapat bersifat reguler atau penugasan. Specific-purpose transfers digunakan untuk program atau kegiatan yang dianggap penting oleh pemerintah pusat namun kurang dianggap penting oleh daerah. Sehingga transfer ini dimaksudkan untuk memberikan insentif bagi pemerintah daerah untuk melakukan program atau kegiatan sesuai keinginan pemerintah pusat (Shah, 2007). Transfer bersyarat biasanya 
menentukan jenis pengeluaran yang dapat dibiayai (persyaratan berbasis input), bisa juga berdasarkan pencapaian hasil tertentu dalam pemberian layanan (persyaratan berbasis hasil). Persyaratan berbasis input seringkali kurang produktif, dibandingkan persyaratan berbasis keluaran.

Transfer bersyarat dapat menambahkan persyaratan, dengan mewajibkan penerima hibah untuk turut mendanai atau dana penyertaan dalam persentase tertentu dari sumber daya mereka sendiri. Transfer bersyarat dapat bersifat terbuka atau openended, yang berarti bahwa pemerintah pusat menyediakan dana sesuai dengan kebutuhan penerima bantuan berapapun yang dibutuhkan. Bersifat tertutup atau closeended, yang berarti bahwa dana yang akan disalurkan pemberi bantuan sudah ditetapkan di awal nanti kekurangannya ditutupi oleh pemerintah lokal.

Transfer nonmatching bersyarat memberikan tingkat dana tertentu tanpa kesesuaian dengan daerah, selama dana tersebut dihabiskan untuk tujuan tertentu (Shah, 2007). Garis (AC), garis anggaran dalam Gambar 2 bergeser dari AB ke ACD, di mana setidaknya OE (=AC) akan diperoleh dari barang publik yang dibantu. Hibah conditional nonmatching transfers paling cocok untuk kegiatan subsidi yang dianggap prioritas tinggi oleh pemerintah pusat, tetapi prioritas rendah oleh pemerintah daerah. Kasus ini terjadi, jika suatu program menghasilkan tingkat limpahan yang tinggi hingga tingkat tertentu sesuai yang diberikan (OE).

Untuk tingkat tertentu dari bantuan yang tersedia, penerima hibah lebih suka transfer tanpa syarat, yang memberi mereka fleksibilitas maksimum untuk mencapai tujuan mereka sendiri. Karena hibah semacam itu menambah sumber daya tanpa memengaruhi pola pengeluaran, memungkinkan penerima untuk memaksimalkan kesejahteraannya.

Matching transfers, atau program kemitraan pembiayaan, mengharuskan agar dana dibelanjakan untuk tujuan tertentu dan bahwa penerima menyesuaikan dana tersebut sampai tingkat tertentu.

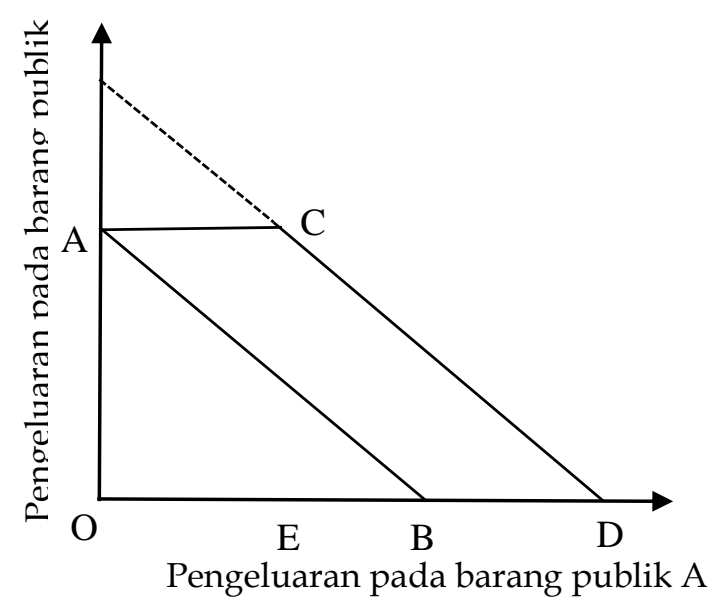

Gambar 2

Hibah Conditional Nonmatching Transfers Sumber: Shah, 2007

Gambar 2 menunjukkan efek pada anggaran pemerintah daerah dari program subsidi 25 persen untuk transportasi.

Garis $A B$ menunjukkan jika tidak ada subsidi misalkan kombinasi transportasi barang dan jasa publik lainnya yang dapat diperoleh sebuah daerah dengan anggaran $\mathrm{OA}=$ OB. Misal subsidi pusat sebesar 25 persen dari pengeluaran transportasi (yaitu, hibah Rp. 1 untuk setiap Rp. 3 dana lokal yang dihabiskan untuk transportasi) menggeser garis anggaran kombinasi yang dapat dicapai ke AC. Pada setiap tingkat barang dan jasa lain, masyarakat dapat memperoleh satu-tiga lebih banyak layanan transportasi.

Jika masyarakat sebelum adanya hibah memilih kombinasi $\mathrm{M}$, akan memilih kombinasi $\mathrm{N}$ sesudah ada hibah. Di N, lebih banyak transportasi diperoleh. Subsidi memiliki dua efek, efek pendapatan, dan efek substitusi. Subsidi memberi masyarakat lebih banyak sumber daya, beberapa di antaranya digunakan untuk memperoleh lebih banyak layanan transportasi (efek pendapatan). Karena subsidi mengurangi harga relatif layanan transportasi, masyarakat memperoleh lebih banyak layanan transportasi dari anggaran tertentu (efek substitusi). Kedua efek merangsang 
pengeluaran yang lebih tinggi untuk transportasi. Meskipun hibah untuk transportasi, lebih banyak barang dan jasa publik lainnya juga dapat diperoleh, meskipun mereka menjadi relatif lebih mahal, sebagai akibat dari efek substitusi. Jika efek pendapatannya cukup besar, itu akan mendominasi dan hibah akan meningkatkan konsumsi barang dan jasa lainnya.

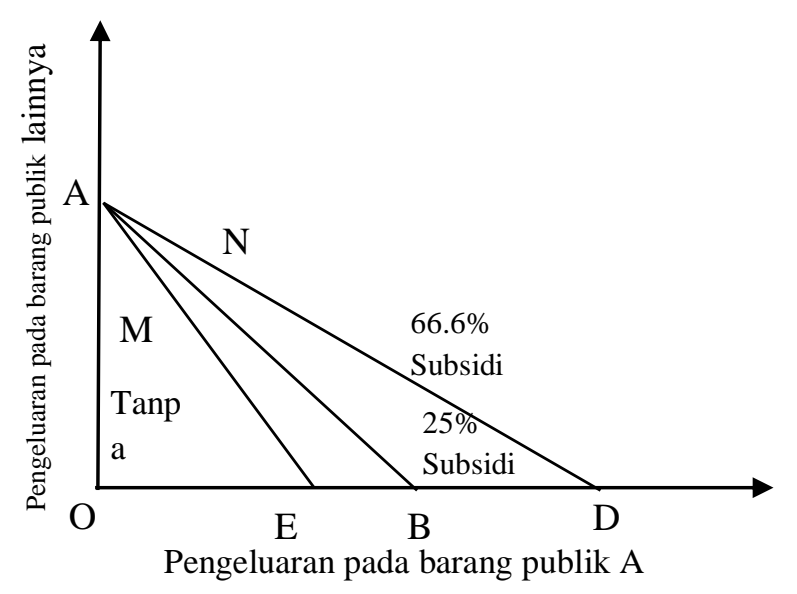

\section{Gambar 3 Matching Transfer \\ Sumber: Shah, 2007}

Pemerintah pusat mengalokasikan dana mentransfer ke daerah dalam APBN sebagai konsekuensi diberlakukannya otonomi. Dana transfer terdiri dari Dana Perimbangan atau Daper, Dana Insentif Daerah, Dana Otonomi Khusus, Dana Keistimewaan dan Dana Desa. Dana Desa adalah dana yang dialokasikan dalam Anggaran Pendapatan dan Belanja Negara yang diperuntukkan bagi desa yang ditransfer melalui Anggaran Pendapatan dan Belanja. Kejelasan kewenangan pemda akan memperbaiki kualitas penyediaan pelayanan publik maupun pengelolaan sarana prasarana publik dalam rangka melaksanakan money follows function (Setiawan, 2018).

Pendapatan asli daerah atau PAD adalah penerimaan daerah yang berasal dari sumber ekonomi asli daerah. Berdasarkan Undang-Undang No. 32 tahun 2004 pasal 6 pendapatan asli daerah berasal dari: pajak daerah, retribusi daerah, hasil pengelolaan kekayaan daerah yang dipisahkan, penerimaan dari dinas dan pendapatan yang sah. Dana Bagi Hasil atau DBH adalah dana yang bersumber dari pendapatan APBN yang dialokasikan kepada daerah penghasil berdasarkan angka persentase tertentu dengan tujuan mengurangi ketimpangan kemampuan keuangan antara pemerintah pusat dan daerah. DAU adalah dana yang bersumber dari pendapatan APBN yang dialokasikan dengan tujuan pemerataan kemampuan keuangan antar-daerah untuk mendanai kebutuhan daerah dalam rangka pelaksanaan desentralisasi. Dana Alokasi Khusus atau DAK adalah dana yang bersumber dari pendapatan APBN yang dialokasikan kepada daerah tertentu dengan tujuan untuk membantu mendanai kegiatan khusus yang merupakan urusan pemerintahan yang menjadi kewenangan daerah (UU, 2014).

Belanja pemerintah sektor pendidikan akan berpengaruh terhadap perkembangan di sektor pendidikan yaitu dengan meningkatnya jumlah murid yang mampu menyelesaikan sekolahnya sampai ke tingkat yang lebih tinggi (meningkatkan rata-rata lama sekolah). Semakin tinggi ratarata lama sekolah akan meningkatkan tingkat pengetahuan dan keterampilan yang dimiliki oleh masyarakat, maka semakin mudah bagi setiap individu dalam usia bekerja untuk mendapatkan pekerjaan, menerapkan, dan mendapatkan hasil dari kemajuan teknologi dan akhirnya meningkatkan standar ekonomi. Investasi sektor pendidikan mutlak dibutuhkan untuk membangun sarana dan prasarana pendidikan yang baik (Todaro, 2010). Alokasi anggaran pendidikan merupakan wujud nyata dari investasi untuk meningkatkan produktivitas masyarakat.

Belanja pemerintah merupakan salah satu mesin pertumbuhan ekonomi, sedangkan rumah tangga dan perusahaan melakukan transaksi atas faktor-faktor produksi dan produk yang dihasilkan di pasar. Disamping aktivitas belanja, pemerintah menghasilkan barang dan jasa publik yang diperlukan oleh rumah tangga, sehingga 
pemerintah berpengaruh secara langsung maupun tidak terhadap aktivitas rumah tangga dan perusahaan.

$Y=C+G+I+(X-M)$

Dimana:

G : belanja pemerintah

C : konsumsi rumah tangga

I : investasi swasta

X-M : ekspor netto

Persamaan di atas merupakan pembentuk pendapatan nasional, seperti dirumuskan dalam persamaan (Mankiw, 2006) Belanja pemerintah dipandang sebagai mesin pertumbuhan endogen jangka panjang guna meningkatkan pemanfaatan modal dan tenaga kerja hingga ke level steady state. Besar kecilnya belanja pemerintah menentukan pertumbuhan ekonomi jangka panjang (Romer, 2006). Teori belanja publik dibangun atas asumsi kuantitas dan kualitas belanja yang signifikan (Samuelson, 1958).

\section{Indeks Pembangunan Manusia}

Indeks pembangunan manusia atau IPM adalah ukuran rata-rata geometris pencapaian dimensi kunci pembangunan manusia yang meliputi: kehidupan yang panjang dan sehat, pendidikan dan memiliki standar kehidupan yang layak. Dimensi kesehatan menggunakan indikator harapan hidup saat lahir, dimensi pendidikan diukur dengan rata-rata (tahun) lama sekolah untuk orang dewasa berusia 25 tahun atau lebih, dan harapan lama sekolah (tahun) untuk anak-anak usia sekolah. Dimensi standar hidup yang layak diukur dengan pendapatan nasional bruto per kapita. Sebuah negara dengan nilai IPM yang lebih tinggi akan diperoleh saat usianya lebih lama, tingkat pendidikannya lebih tinggi, dan PDB per kapita lebih tinggi (BPS, 2016). Nilai minimum dan maksimum ditetapkan untuk mengubah indikator yang dinyatakan dalam unit yang berbeda menjadi indeks pada skala 0 sampai 1.

Setelah menentukan nilai minimum dan maksimum, indeks dihitung sebagai:

indeks dimensi $=\frac{\text { nilai aktual }- \text { nilai } \min }{\text { nilai maks }- \text { nilai min }}$
Untuk dimensi pendidikan, persamaan di atas pertama kali diterapkan pada masing-masing dua indikator, dan kemudian ambil mean aritmetik dari dua indeks yang dihasilkan. Karena setiap indeks adalah proxy untuk kemampuan dalam dimensi yang sesuai, fungsi transformasi dari pendapatan cenderung bersifat cekung (Anand dan Sen, 2000) jadi untuk pendapatan digunakan logaritma alami dari nilai aktual, minimum dan maksimum.

Dalam Laporan Pembangunan Manusia 2010, mulai menggunakan metode baru untuk menghitung IPM. Berikut tiga indeks yang digunakan:

Indeks Harapan Hidup ( $\mathrm{I}_{\text {healt }}$ )

$$
\mathrm{I}_{\text {Healt }}=\frac{\mathrm{LE}-20}{85-20}
$$

Indeks Pendidikan ( $\left.\mathrm{I}_{\text {education }}\right)$

$$
\mathrm{I}_{\text {education }}=\frac{\text { MYSI }+ \text { EYSI }}{2}
$$

Indeks Rata-Rata Lama Sekolah (MYSI)

$$
\text { MYSI }=\frac{\text { MYS }}{15}
$$

Indeks Lama Sekolah yang Diharapkan (EYSI):

$$
\text { EYSI }=\frac{E Y S}{18}
$$

Indeks Penghasilan ( $\left.\mathrm{I}_{\text {income }}\right)$

$$
\mathrm{I}_{\text {income }}=\frac{\ln _{-}(\mathrm{GNIPc})-\ln _{-}(100)}{\ln \_(75.000)-\ln _{-}(100)}
$$

HDI adalah mean geometrik dari indeks tiga dimensi:

$$
\text { HDI }=\sqrt[3]{\mathrm{I}_{\text {health }} \times \mathrm{I}_{\text {education }} \times \mathrm{I}_{\text {income }}}
$$

\section{Biaya dan Manfaat Individual Versus Biaya dan Manfaat Sosial}

Alasan seseorang untuk sekolah mungkin bukan bersifat ekonomis, namun untuk simplikasi bisa dijelaskan secara ekonomis sebagai proses supply dan demand. Seorang individu akan menanggung biaya yang harus dikeluarkan untuk memperoleh pendidikan. Dari segi permintaan ada beberapa alasan kenapa seseorang ingin bersekolah antara lain (Todaro, 2010): alasan pertama, besar kecilnya selisih upah antara sektor moderen dan tradisionil. Orang yang pendidikannya tinggi bisa diterima di sektor 
modern, sedangkan yang pendidikannya rendah mungkin hanya bisa diterima di sektor tradisionil, makin tinggi selisih upah antara sektor modern dengan sektor tradisionil maka permintaan akan pendidikan akan semakin meningkat; alasan kedua peluang untuk bekerja di sektor modern. Orang yang pendidikannya tinggi peluang untuk bisa bekerja di sektor modern lebih tinggi, namun jika pengangguran semakin banyak dan penciptaan lapangan kerja cukup sedikit, maka kriteria selisih upah akan bergeser menjadi mudah atau tidaknya peluang untuk memperoleh pekerjaan. Berdasarkan hal tersebut, untuk memaksimalkan maka seseorang akan sekolah setinggi-tingginya.
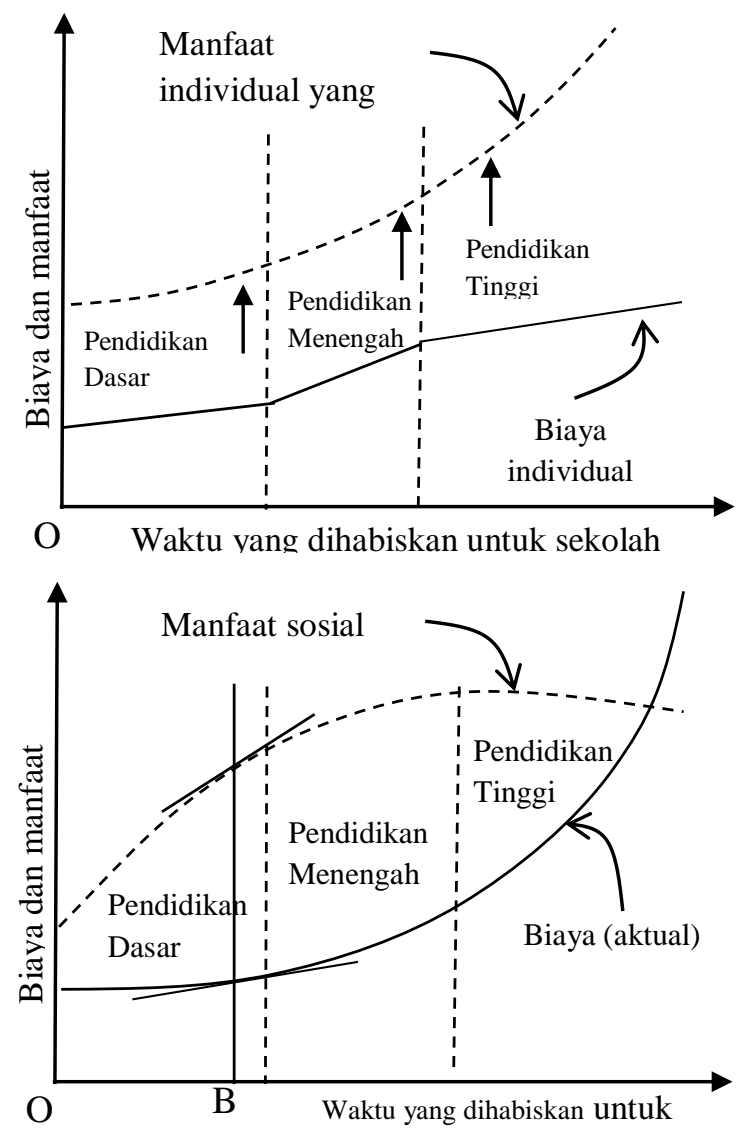

\section{Gambar 4 \\ Biaya dan Manfaat Individual Versus Sumber: Todaro, 2010 Biaya dan Manfaat Sosial}

Berbarengan dengan semakin tingginya biaya pendidikan, biaya sosial yang di- tanggung oleh masyarakat juga akan semakin tinggi. Biaya oportunitas yang ditanggung akan semakin tinggi dengan kesediaan untuk membiayai perluasan pendidikan tinggi yang semakin mahal, karena biaya yang dikeluarkan untuk pendidikan, bisa saja digunakan untuk kegiatan perekonomian yang lebih produktif yang bisa memberikan keuntungan jika biaya yang dia punya digunakan untuk menciptakan pekerjaan. Manfaat sosial kurvanya menaik dengan tajam, tetapi akan semakin melandai seiring bertambahnya jumlah waktu untuk sekolah. Strategi optimal dipandang dari segi adalah strategi yang mampu menyediakan kesempatan sebanyak mungkin bagi peserta didik, minimal sampai B tahun. Tetapi setelah titik B, biaya sosial marginal akan melampaui manfaat sosial marginal.

\section{Penelitian Terdahulu}

Terdapat hubungan antara belanja pendidikan dan kinerja pendidikan melalui variabel moderasi kinerja pemerintah atau good governance (Rajkumar dan Swaroop 2008, 2007). Hasil penelitian menyimpulkan hubungan signifikan dipengaruhi oleh governace (kualitas birokrasi dan indeks korupsi). Belanja pendidikan mempengaruhi kinerja pendidikan dengan pengaruh tata pemerintahan yang baik. Alokasi anggaran pendidikan, anggaran kesehatan, daya beli masyarakat berpengaruh positif terhadap indeks pembangunan manusia (Kahang et al., 2016). Belanja pendidikan mempunyai pengaruh terhadap hasil pendidikan (Hidayat et al. 2012). Belanja pendidikan dipergunakan untuk penyediaan barang input yang akan memberikan dampak pada kinerja pendidikan melalui fungsi alokasi yang tepat (effective), adil (equitable) dan efisien. Belanja merupakan salah satu faktor dalam penyelenggaraan proses belajar mengajar.

Peningkatan pengeluaran belanja pendidikan dan kesehatan dapat memberikan manfaat di bidang sosial dan dapat meningkatkan pembangunan manusia Gupta 
dan Clements (1998). Investasi bidang pendidikan akan menciptakan individu yang terdidik dengan baik, sehingga mampu meningkatkan kemampuan, pengetahuan, keterampilan dan pengalamannya di berbagai sektor bidang ekonomi Asaju dan Kayode (2012). Kemiskinan sama dengan terbelakang, investasi dalam pembangunan manusia melalui pendidikan adalah rencana terbaik untuk menghadapi tantangan pembangunan di masa depan, khususnya mengurangi kemiskinan. menemukan bahwa adanya intervensi belanja pemerintah di bidang pendidikan dan kesehatan mempengaruhi human capital. Peningkatan belanja pemerintah khususnya di bidang pendidikan dan kesehatan mempunyai efek yang sangat kuat dalam peningkatan human capital (Dissou et al., 2016).

\section{Hipotesis Penelitian}

Berdasarkan uraian di atas maka dapat dibuatkan hipotesis sebagai berikut: Dana Transfer (DAU, DAK, DBH dan Pendapatan lainnya yang sah), Pendapatan Asli Daerah atau PAD, dan dana desa berpengaruh terhadap Indeks Pembangunan Manusia atau IPM.

\section{METODE PENELITIAN}

Data dalam penelitian ini terdiri dari 25 kabupaten atau kota dari keseluruhan 27 kabupaten atau kota yang ada di Jawa Barat, dua kabupaten baru hasil pemekaran yaitu Pangandaran dan Kabupaten Bandung Barat tidak disertakan dalam penelitian karena keterbatasan kelengkapan data. Titik waktu dalam penelitian ini dari tahun 2010-2016.

\section{Fixed Effect atau Model Efek Tetap}

Model efek tetap (fixed effect model atau FEM), menggunakan pendekatan persamaan sebagai berikut:

$$
Y_{i t}=\alpha_{i}+\sum_{i=1}^{N} \beta_{i} X_{i t}+u_{i t}
$$

Dengan derajat bebas atau degree of freedom $N T-N-T$.

\section{Pengujian Asumsi}

Sebelum dilakukan analisis regresi, ada beberapa persyaratan yang harus dipenuhi, antara lain:

1. Multikolinearitas; dalam model regresi berganda diasumsikan tidak ada kombinasi linear antar peubah bebas (Juanda, 2009). Salah satu uji yang bisa dilakukan adalah melihat variance inflation factor $V I F=1 /\left(1-R_{i}^{2}\right)$, jika VIF $>10$ merupakan signal adanya multikolinearitas.

2. Autokorelasi, tidak ada korelasi serial antara sisaan atau dengan kata lain sisaan menyebar bebas $\operatorname{cov}\left(u_{i}, u_{j}\right)=0$. Statistik uji menggunakan uji Durbin-Watson:

$$
D W=\frac{\sum\left(e_{i}-e_{i-1}\right)^{2}}{\sum e_{i}^{2}} \approx 2(1-\rho)
$$

3. Uji Chow

Uji Chow digunakan untuk memilih apakah menggunakan model common effect atau model fixed effect (Meutuah et al. 2017; Alwi at al. 2019).

$$
F=\frac{\frac{R R S S-U R S S}{n-1}}{\frac{U R S S}{N T-p}}
$$

Dimana:

RRSS: restricted residual sum of squares model common effect

URSS: unrestricted residual sum of squares model fixed effect

Hipotesis:

$H_{0} \quad$ : common effect model

$H_{1}$ : fixed effect model

\section{Uji Hausman}

Uji Hausman digunakan untuk memilih apakah menggunakan model efek acak (random effect model) atau menggunakan model efek tetap (fixed effect model).

$$
W=\widehat{\boldsymbol{q}}^{\prime}\left[\operatorname{var}\left(\widehat{\boldsymbol{q}}^{\prime}\right)\right]^{-1} \widehat{\boldsymbol{q}}
$$

Statistik $W$ mengikuti distribusi Chi Kuadrat.

$$
W \sim \chi_{(\alpha, d b)}^{2}
$$

Dimana:

$\widehat{\boldsymbol{\beta}}_{M E T}$ : vektor esmasi slope model efek tetap $\widehat{\boldsymbol{\beta}}_{M E A}$ : vektor esmasi slope model efek acak Hipotesis: 
$H_{0}$ : random effect model

$H_{1}$ : fixed effect model atau model efek tetap

\section{Pendekatan Model}

Untuk melihat pengaruh dana transfer terhadap indeks pembangunan manusia melalui peubah antara belanja pemerintah daerah, sehingga dilakukan sebanyak dua tahapan regresi;

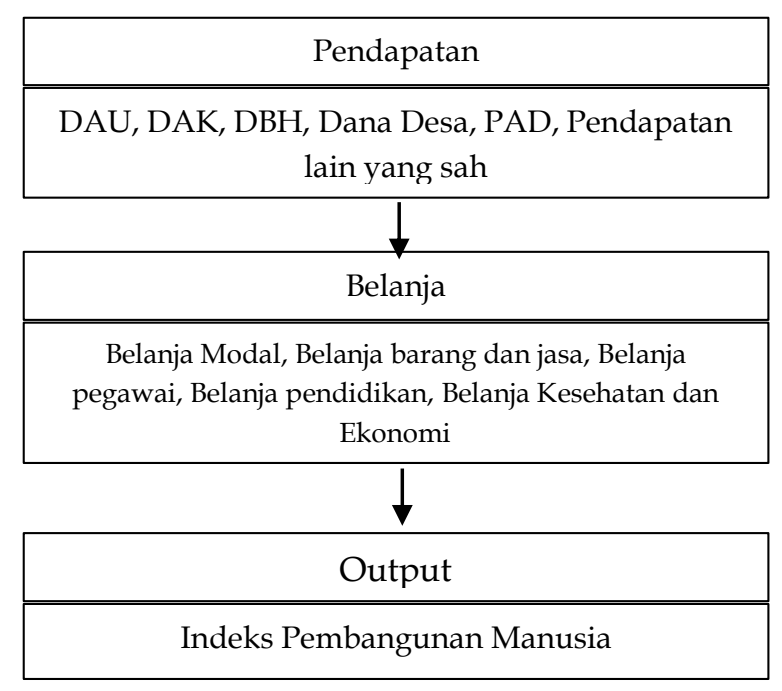

\section{Gambar 6 \\ Pendekatan model penelitian}

\section{Pendapatan ke Output Melalui Belanja}

Tahap pertama melakukan regresi dari pendapatan daerah terhadap belanja, masing-masing terhadap belanja pendidi- kan; kesehatan; barang dan jasa; belanja ekonomi, belanja pegawai dan belanja modal. Tahapan kedua melakukan analisis regresi dari belanja terhadap indeks pembangunan manusia, seperti terlihat pada Gambar 5 yang diadopsi dari Juanda et al. (2017).

Berdasarkan Gambar 5 di atas maka akan diperoleh persamaan pendapatan terhadap belanja sebagai berikut:

- In_bmodal $_{i t}=\beta_{0}+\beta_{1} \ln \_$pad $_{i t}+$ $\beta_{2} \ln _{-} \mathrm{dbh}_{i t}+\beta_{3} \ln _{-} \mathrm{dau}_{i t}+\beta_{4} \ln _{-} \mathrm{dak}_{i t}+$ $\beta_{5} \ln _{-}$pendlainsah ${ }_{i t}+\beta_{6} \ln _{-}$ddesa $_{i t}+\varepsilon_{i t}$

- $\ln \_$bbarang $_{i t}=\beta_{0}+\beta_{1} \ln \_$pad $_{i t}+$ $\beta_{2} \ln \_\mathrm{dbh}_{i t}+\beta_{3} \ln \_\mathrm{dau}_{i t}+\beta_{4} \ln _{-} \mathrm{dak}_{i t}+$

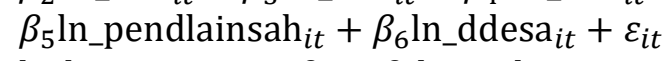

- ln_bpegawai ${ }_{i t}=\beta_{0}+\beta_{1} \ln \_p a d_{i t}+$ $\beta_{2} \ln _{-} \mathrm{dbh}_{i t}+\beta_{3} \ln _{-} \mathrm{dau}_{i t}+\beta_{4} \ln _{-} \mathrm{dak}_{i t}+$

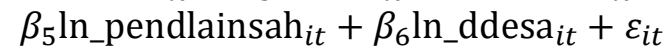

- ln_bpendidikan $_{i t}=\beta_{0}+\beta_{1} \ln _{-}$pad $_{i t}+$

- $\beta_{2} \ln _{-} \mathrm{dbh}_{i t}+\beta_{3} \ln _{-} \mathrm{dau}_{i t}+\beta_{4} \ln _{-} \mathrm{dak}_{i t}+$

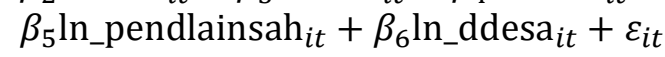

- In_bkesehatan ${ }_{i t}=\beta_{0}+\beta_{1} \ln _{-}$pad $_{i t}+$ $\beta_{2} \ln _{-} \mathrm{dbh}_{i t}+\beta_{3} \ln \_\mathrm{dau}_{i t}+\beta_{4} \ln _{-} \mathrm{dak}_{i t}+$ $\beta_{5} \ln _{-}$pendlainsah $i t+\beta_{6} \ln _{-}$ddesa $_{i t}+\varepsilon_{i t}$

- ln_bekonomi ${ }_{i t}=\beta_{0}+\beta_{1} \ln \_p a d_{i t}+$ $\beta_{2} \ln _{-} \mathrm{dbh}_{i t}+\beta_{3} \ln \mathrm{dau}_{i t}+\beta_{4} \ln _{-} \mathrm{dak}_{i t}+$

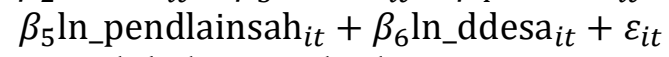
Pengaruh belanja terhadap output:

- $\operatorname{ipm}_{i t}=\beta_{0}+\beta_{1} \ln _{-}$bmodal $_{i(t-k)}+$ $\beta_{2} \ln _{-}$bbjasa $_{i(t-k)}+$ $\beta_{3} \ln _{-}$bpendidikan $_{i(t-k)}+$

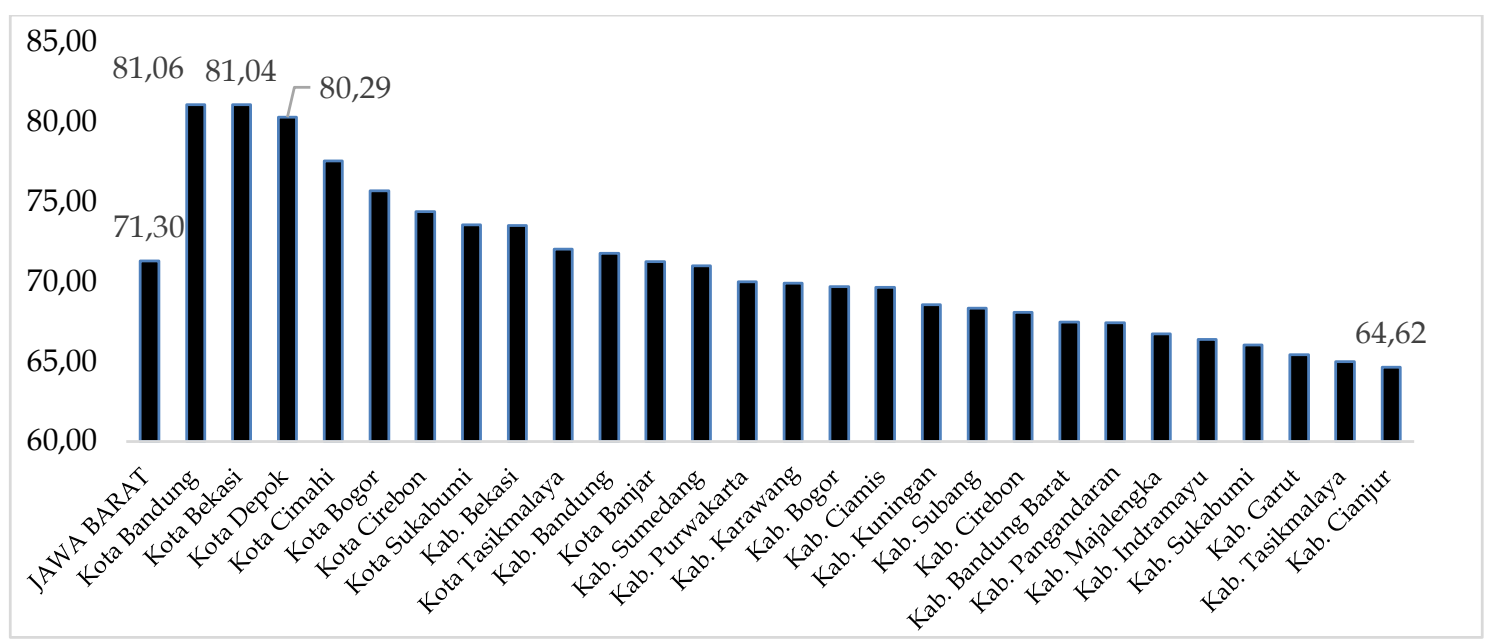

Gambar 7

Skor IPM Kabupaten atau Kota di Provinsi Jawa Barat tahun 2018

Sumber: Bappenas; Data diolah 


$$
\begin{aligned}
& \beta_{4} \ln \_ \text {bkesehatan }_{i(t-k)}+ \\
& \beta_{5} \ln \_ \text {bekonomi } \\
& i(t-k) \\
& +\varepsilon_{i t}
\end{aligned}
$$

\section{ANALISIS DAN PEMBAHASAN Skor IPM Kabupaten atau Kota di Jawa barat}

Kualitas sumberdaya manusia di suatu kawasan bisa diketahui dari skor IPM di daerah tersebut, karena indikator IPM menggambarkan kualitas pendidikan, kesehatan dan kesejahteraan hidup. Gambar 7 memperlihatkan skor IPM berdasarkan kabupaten atau kota yang ada di Jawa Barat tahun 2018, dari gambar tersebut diketahui skor IPM Provisi Jawa Barat sebesar 71,30. Sebelumnya Provinsi Jawa Barat mencanangkan untuk sampai pada IPM 80, pada tahun 2022, pekerjaan yang berat mengingat tahun 2018 baru pencapai skor 71,30 dan baru ada tiga kota dari 27 kabupaten atau kota. Tiga kota yang sudah mencapai IPM 80 pada tahun 2018 yaitu: Kotamadya Bandung, Kotamadya Depok dan Kotamadya Cimahi. Dari Gambar 6 bisa disimpulkan bahwa kondisi sumberdaya manusia di kotamadya sudah relatif lebih tinggi dibandingkan provinsi secara umum. Skor IPM seluruh kotamadya sudah di atas skor IPM Provinsi Jawa Barat (hanya Katamadya Banjar yang skornya selisih lebih rendah dari rata-rata Provinsi Jawa Barat, yaitu 0.05), sedangkan untuk kabupaten, hanya Kabupaten Bekasi dan Kabupaten Bandung yang skornya di atas IPM provinsi.

\section{Pendapatan Daerah}

Pendapatan daerah adalah semua hak daerah yang diakui sebagai penambah nilai kekayaan bersih dalam periode tahun anggaran yang bersangkutan (UU No. 23 tahun 2014). Untuk menjalankan urusan pemerintahan yang menjadi kewenangannya, daerah harus mempunyai sumber keuangan agar mampu memberikan pelayanan dan kesejahteraan kepada rakyat. Pemberian sumber keuangan kepada daerah harus seimbang dengan beban atau urusan pemerintahan yang diserahkan kepada daerah. Gambar 8 di bawah menyatakan rata-rata pendapatan pemerintah daerah (dalam milyar rupiah) dari tahun 2011-2016. Rata-rata pendapatan diperoleh dengan menjumlahkan tiap komponen pendapatan daerah pada tahun fiskal tersebut dibagi dengan banyaknya kabupaten atau kotamadya. DAU merupakan komponen transfer dari pusat yang nilai rata-ratanya paling besar diperoleh oleh pemerintah kabupaten atau kota, rata-rata besaran alokasi DAU terus meningkat pada tahun 2011 rata-rata sebesar Rp. 752.45 milyar, menjadi Rp. 1,206.80 milyar pada tahun 2016 walaupun begitu tren peningkatannya terlihat penurunan.

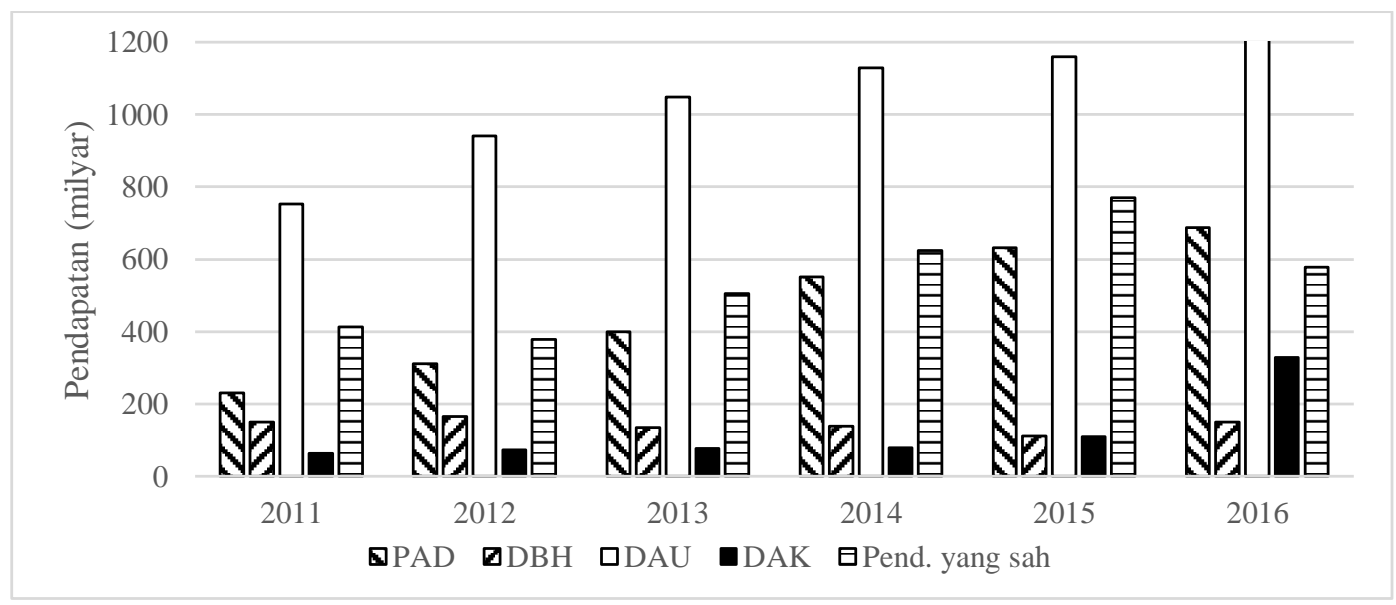

Gambar 8

Rata-Rata Pendapatan (dalam milyar rupiah) Kabupaten atau Kota di Provinsi Jawa Barat Tahun 2011-2016

Sumber: Bappenas; Data diolah 
Pendapatan Asli Daerah atau PAD pada tahun 2011 menempati urutan ketiga setelah DAU dan Pendapatan lain yang sah, besarannya terus mengalami peningkatan dari tahun ke tahun. Jika pada tahun 2011 rata-rata PAD kabupaten atau kotamadya di Jabar sebesar Rp. 130.50 milyar rupiah, maka pada tahun 2016 telah mencapai nilai Rp. 686.98 milyar rupiah berarti telah naik lebih dari 5 kali lipat dan menempati urutan ke dua setelah DAU. Ini tentu hal yang sangat menggembirakan, dan diharapkan trennya terus meningkat, sehingga ketergantungan pada dana transfer bisa berkurang. Pendapatan Asli Daerah menggambarkan kemandirian suatu wilayah, semakin besar persentase PAD terhadap total pendapatan daerah, berarti semakin berkurang ketergantungannya kepada tranfer dari pusat. PAD tidak dibatasi dalam hal penggunaannya, tidak seperti dana transfer dimana sebagian penggunaannya sudah ditentukan dari pemerintah pusat.

Hal yang menarik lain untuk diperhatikan adalah Dana Alokasi Khusus nilainya relatif kecil dibandingkan pendapatan daerah yang lainnya, besarannya juga relatif konstan sampai tahun 2015, tiba-tiba pada tahun 2016 mengalami lonjakan cukup signifikan, pada tahun 2015 rata-rata DAK kabupaten atau kota di Jawa Barat sebesar
Rp. 109.70 naik hampir tiga kali lipat menjadi Rp. 328.93 milyar, ini bisa terjadi setelah diberlakukannya DAK berbasis proposal, dan ruang lingkupnya yang lebih diperluas baik untuk DAK Fisik maupun DAK Nonfisik, besarnnya mencapai tiga kali lipat dari nilai DAK tahun 2015.

\section{Belanja Pemerintah Daerah}

Belanja Daerah adalah semua kewajiban Daerah yang diakui sebagai pengurang nilai kekayaan bersih dalam periode tahun anggaran yang bersangkutan. Gambar 9 menggambarkan pengeluaran untuk belanja pemerintah daerah untuk beberapa komponen antara lain belanja pegawai, belanja barang dan jasa, belanja bantuan sosial, belanja hibah, belanja modal dan belanja lainnya. Berdasarkan gambar tersebut komponen untuk belanja pegawai (baik untuk belanja langsung maupun tidak langsung) menduduki nilai paling tinggi dari tahun ke tahun, walaupun terlihat ada perlambatan.

Untuk belanja hibah dan bantuan sosial serta belanja lain persentasenya cukup kecil jika dibandingkan dengan belanja pegawai, belanja barang dan jasa serta belanja modal. Gambar 9 memperlihatkan besaran belanja pemerintah daerah, berdasarkan gambar tersebut terlihat belanja untuk pegawai

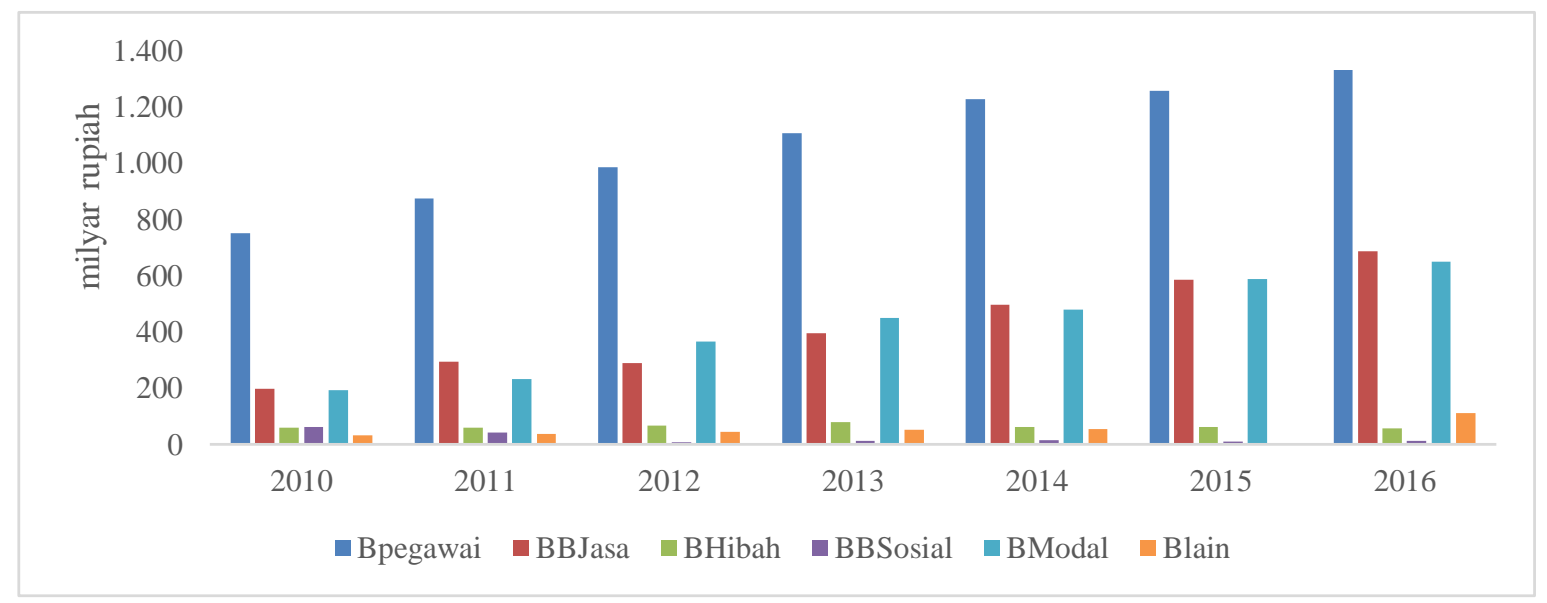

\footnotetext{
Gambar 9

Rata-rata jumlah belanja kabupaten atau kota (milyar rupiah) di Provinsi Jawa Barat tahun 2010-2016

Sumber: DJPK, Kemenkeu; Data diolah

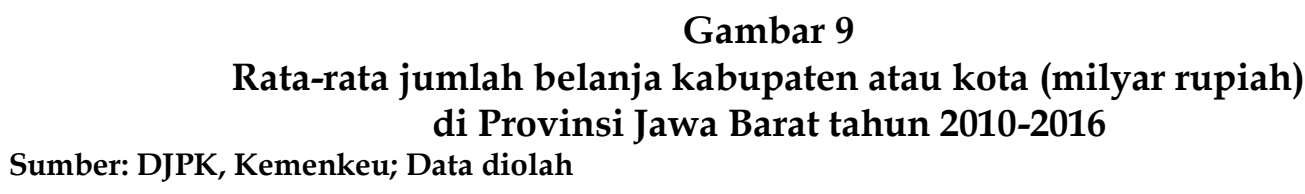


paling tinggi, tetapi persentasenya semakin menurun seiring dengan semakin naiknya persentase untuk belanja barang dan jasa serta belanja modal. Jika belanja pemerintah daerah masih didominasi untuk belanja pegawai maka porsi untuk belanja pembangunan akan semakin kecil. Selama ini belanja untuk pegawai paling besar berasal dari alokasi dasar berarti berasal dari DAU yang merupakan transfer pusat. Karena dibebankan pada APBN maka bisa menjadi sinyalemen bagi pemerintah daerah untuk menambah jumlah pegawainya, harusnya belanja pegawai dibebankan kepada APBD walau tidak benar-benar seratus persen, sehingga pemerintah akan melakukan kalkulasi ulang kalau ingin menambah jumlah pegawai.

Tabel 1 di bawah memperlihatkan pengaruh dana transfer terhadap belanja berdasarkan jenis dan fungsi. Belanja berdasarkan jenis terdiri dari belanja modal (ln_bmodal), belanja barang dan jasa (ln_bbjasa), belanja pegawai (ln_bpegawai). Belanja berdasarkan fungsi terdiri dari belanja pendidikan (ln_bdidik), belanja kesehatan (ln_bsehat), belanja ekonomi (ln_bekonomi). Untuk mendapatkan nilai elastisitas, maka data ditransformasikan ke logaritma naturalkan terlebih dahulu.

\section{Belanja Modal}

Belanja modal, adalah pengeluaran yang dilakukan dalam rangka pembentukan modal yang sifatnya menambah aset tetap, memberikan manfaat lebih dari satu periode akuntansi (PMK, 2015). Komponen belanja modal meliputi: belanja tanah, belanja peralatan dan mesin, belanja gedung dan bangunan, belanja jalan, belanja irigasi dan jaringan, belanja aset tetap, dan belanja aset lainnya, termasuk pengeluaran untuk biaya pemeliharaan yang sifatnya menambah waktu masa manfaat, meningkatkan kapasitas dan kualitas aset. Belanja modal harus ditunjukkan untuk program-program yang mampu mendorong pertumbuhan ekonomi dengan mengarahkan pada belanja modal produktif, seperti pembangunan infrastruktur di kawasan 3T, sarana dan prasarana ekonomi produktif. Persamaan umum untuk belanja modal dapat dilihat pada persamaan (10):

$$
\begin{aligned}
& \text { ln_bmodal }_{\text {it }} \\
& =12,706+0.047 \ln _{-} \mathrm{dak}_{i t}+0,506 \mathrm{ln}_{-} \mathrm{dau}_{i t} \\
& +0,015 \ln _{-} \mathrm{dbh}_{i t}+0,007 \mathrm{ln}_{-} \mathrm{ddesa}{ }_{i t}
\end{aligned}
$$

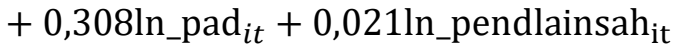

$$
\begin{aligned}
& +e_{i t}
\end{aligned}
$$

Berdasarkan Tabel 1 dan persamaan di atas, semua peubah berpengaruh terhadap belanja modal, dengan taraf nyata yang bervariasi. Peubah yang elastisitasnya paling tinggi secara berurutan adalah, dana alokasi umum atau DAU, pendapatan asli daerah (PAD), dana alokasi khusus atau DAK (Pelealu AM. 2013), pendapatan lain yang sah, dana bagi hasil atau DBH, serta dana desa atau DD. Berdasar koefisien regresi

Tabel 1

Pengaruh PAD dan Dana Transfer Terhadap Belanja Daerah

\begin{tabular}{lrrrrrr}
\hline \hline Peubah & ln_bmodal & ln_bbjasa & ln_bpegawai & ln_bpendidikan & ln_bkesehatan & ln_bekonomi \\
\hline C & $12.706^{* * *}$ & -3.014 & $5.445^{* * *}$ & $13.487^{* * *}$ & 3.678 & -3.253 \\
ln_dak & $0.047^{* * *}$ & $0.061^{* * *}$ & $0.010^{* *}$ & $0.016^{* *}$ & $0.153^{* * *}$ & $0.050^{* *}$ \\
ln_dau & $0.506^{* * *}$ & $0.743^{* * *}$ & $0.468^{* * *}$ & $0.411^{* * *}$ & $0.176^{* *}$ & $0.843^{* * *}$ \\
ln_dbh & $0.015^{* * *}$ & -0.114 & 0.000 & -0.073 & - & - \\
ln_ddesa & $0.007^{* *}$ & $0.012^{* *}$ & - & $0.033^{* *}$ & $0.025^{* * *}$ & 0.003 \\
ln_pad & $0.308^{* * *}$ & $0.345^{* * *}$ & $0.128^{* * *}$ & $0.008^{*}$ & $0.406^{* * *}$ & $0.191^{* * *}$ \\
ln_pendlainsah & $0.021^{* * *}$ & $0.144^{* * *}$ & $0.016^{* *}$ & $0.070^{* *}$ & -0.041 & 0.025 \\
AR(1) & & $0.282^{* * *}$ & $0.344^{* * *}$ & & - & - \\
\hline Adj. R-squared & 0.933 & 0.954 & 0.994 & 0.976 & 0.857 & $0.286^{* *}$ \\
Durbin Watson & 1.973 & 1.976 & 1.829 & 2.069 & & 2.986 \\
\hline
\end{tabular}


Persamaan (10), setiap kenaikan dana alokasi umum sebesar $1 \%$ akan menaikan belanja modal sebesar $0,506 \%$ dan setiap kenaikan DAK sebesar 1 persen akan menaikan belanja modal sebesar $0,047 \%$ dengan asumsi ceteris paribus. Dari ini artinya PAD, DAU dan DAK berpengaruh terhadap belanja modal (Hasan M. 2015; Suryana, 2018; Wandira AG, 2013; Suryani F dan Pariani E, 2018). Tabel 1 di atas juga diperoleh $R$ squared adjusted sebesar 0,933 artinya keragaman dari peubah belanja modal mampu dijelaskan oleh keragaman dari peubah bebas DAK, DAU, DBH, Dana Desa, PAD, dan pendapatan lain yang sah sebesar $93,3 \%$ sedangkan sisanya sebesar 6,7\% berasal dari keragaman di luar model.

\section{Belanja Barang dan Jasa}

Belanja barang dan jasa adalah pengeluaran untuk pembelian barang atau jasa yang habis pakai yang dipasarkan maupun tidak dipasarkan, serta pengadaan barang yang dimaksudkan untuk diserahkan atau dijual kepada masyarakat di luar kriteria belanja bantuan sosial serta belanja perjalanan (PMK. 2015). Berdasarkan Tabel 1, maka persamaan belanja barang dan jasa adalah:

$$
\begin{aligned}
& \ln \_b j j a s a_{i t} \\
& =-3,014+0,061 \ln _{-} \mathrm{dak}_{i t}+0,743 \ln _{-} \mathrm{dau}_{i t} \\
& -0,114 \ln _{-} \mathrm{dbh} \mathrm{h}_{i t}+0,012 \mathrm{ln}_{-} \mathrm{ddesa} \mathrm{it}_{i t} \\
& +0,345 \ln _{-} \text {pad }_{i t}+0,144 \mathrm{In}_{-} \text {pendlainsah }{ }_{i t} \\
& +0,282 e_{i(t-1)}
\end{aligned}
$$

Berdasarkan persamaan di atas maka yang paling berpengaruh terhadap belanja barang dan jasa secara berturut-turut berasal dari dana alokasi umum (DAU), pendapatan asli daerah (PAD) dan pendapatan lain yang sah, dimana setiap kenaikan dana alokasi umum sebesar $1 \%$ akan menaikan belanja barang dan jasa sebesar $0.743 \%$, ceteris paribus. Dari persamaan di atas bisa diketahui elastisitas PAD cukup tinggi mempengaruhi belanja barang dan jasa hal ini sesuai dengan hasil penelitian dari Juanda et al. (2017); Arwaty dan Hadiati (2013); Mawarni et al. (2013) yang menyatakan bahwa PAD berpengaruh terhadap belanja barang dan jasa (Haryanto S, 2013).

\section{Belanja Pegawai}

Belanja pegawai adalah kompensasi terhadap pegawai baik dalam bentuk uang maupun dalam bentuk barang, yang harus dibayarkan kepada pegawai pemerintah dalam dan luar negeri, baik kepada pejabat

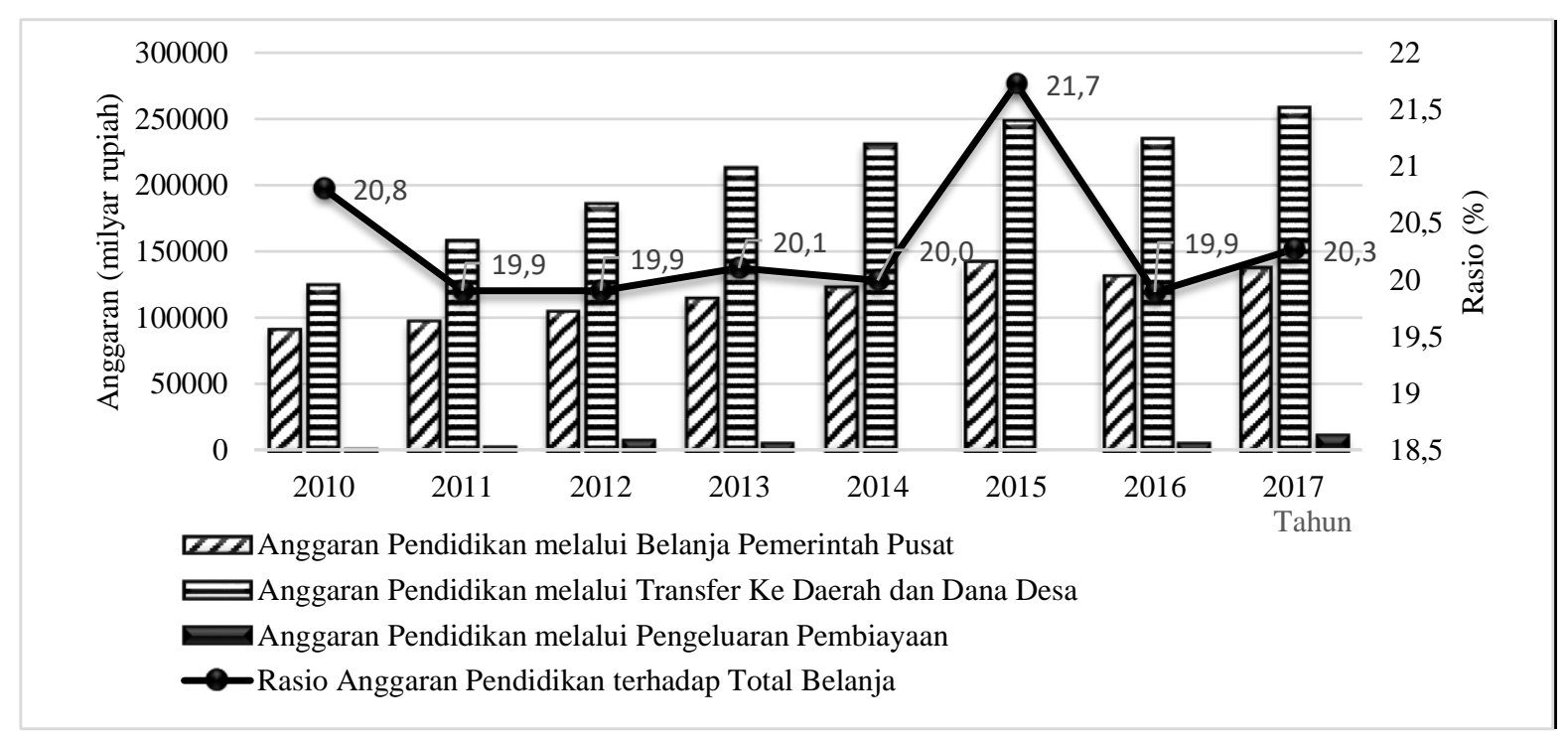

\footnotetext{
Gambar 10

Komponen Realisasi Anggaran Pendidikan (milyar) Tahun 2010-2017

Sumber: Kemenkeu, data diolah
} 
negara, pegawai negeri sipil atau PNS atau non-PNS sebagai imbalan atas pekerjaan yang telah dilaksanakan dalam rangka mendukung tugas fungsi unit organisasi pemerintah (PMK, 2015). Persamaan umum untuk belanja pegawai bisa dilihat pada persamaan berikut:

$\ln \_$bpegawai $_{i t}=5,445+0,010$ ln_dak $_{i t}+$ 0,468 ln_dau $_{i t}+0,128 \ln \_p a d_{i t}+$ 0,016ln_pendlainsah ${ }_{i t}+0,344 e_{i(t-1)}$

Berdasarkan Persamaan (12) di atas, bahwa semua peubah berpenaruh terhadap belanja pegawai. Peubah yang elastisitannya paling tinggi terhadap belanja pegawai secara berurutan adalah DAU, pendapatan asli daerah (PAD), pendapatan lain yang sah dan dana alokasi khusus (DAK). Dana alokasi umum menjadi peubah yang paling berpengaruh terhadap belanja pegawai sangat logis, karena DAU merupakan gabungan dari alokasi dasar dan celah fiskal. Dimana alokasi dasar tidak lain adalah belanja gaji pokok begawai dan calon pegawai negeri sipil daerah (CPNSD), gaji ketigabelas dan tunjangan hari raya. Ke depan alokasi dasar sebagai komponen DAU perlu menjadi pertimbangan, karena bisa menjadi insentif bagi daerah untuk menambah jumlah pegawai. Jika belanja pegawai menjadi tanggung jawab pemerintah daerah, maka penambahan jumlah pegawai akan menjadi pengkajian yang serius, karena akan membebani APBD, atau minimal harus ada persentase yang menjadi tanggung jawab daerah. Sehingga ketika pemerintah daerah akan mengangkat pegawai akan melakukan pengkajian yang mendalam terlebih dahulu.

\section{Belanja Pendidikan}

Anggaran pendidikan adalah alokasi anggaran pada fungsi pendidikan yang dianggarkan melalui Kementerian atau Lembaga, alokasi anggaran pendidikan melalui transfer ke daerah dan dana desa, dan alokasi anggaran pendidikan melalui pengeluaran pembiayaan, termasuk gaji pendidik, tetapi tidak termasuk anggaran pendidikan kedinasan, untuk membiayai penyelenggaraan pendidikan yang menjadi tanggung jawab pemerintah (UU, 2014).

Undang-Undang Dasar tahun 1945, amandemen ke-4, pasal 31, ayat 4 mengamanatkan bahwa negara harus memprioritaskan anggaran pendidikan minimal $20 \%$ dari APBN dan APBD demi memenuhi kebutuhan penyelenggaraan pendidikan nasional. Pembangunan pendidikan dicapai dengan meningkatkan pemerataan akses, kualitas, relevansi, dan daya saing. Alokasi anggaran fungsi pendidikan mencerminkan upaya pemerintah dalam memberikan

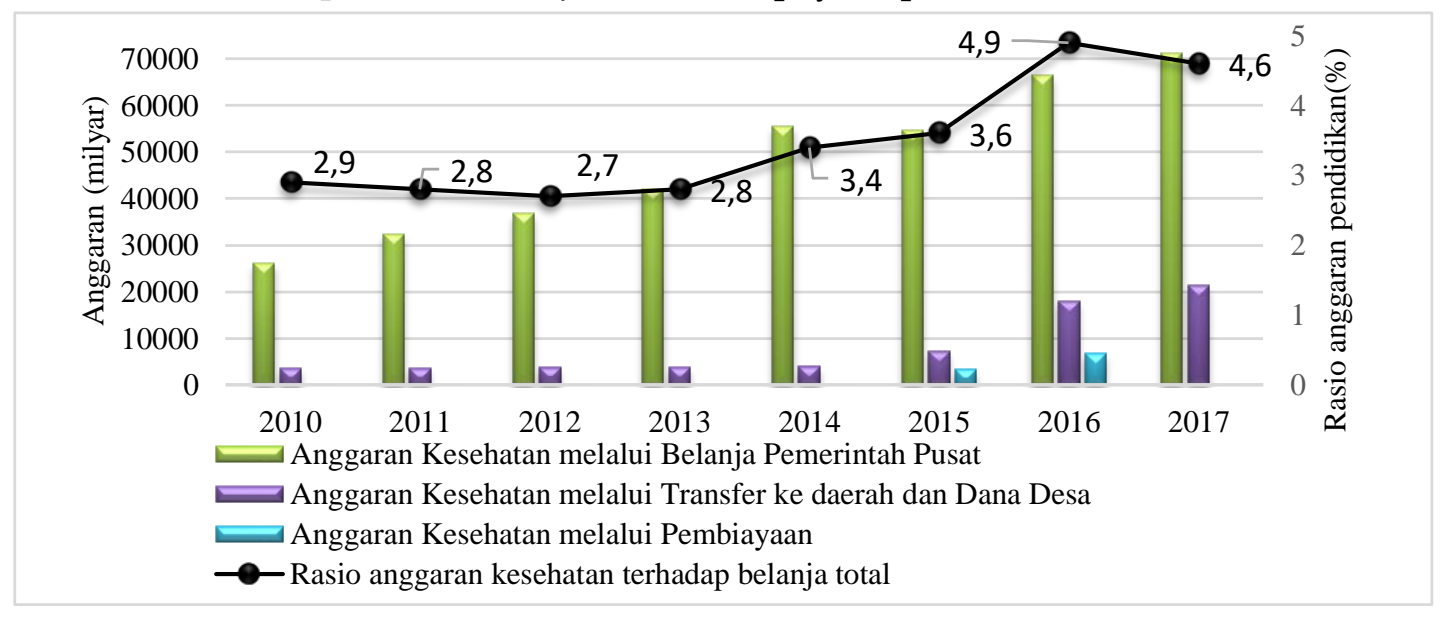

Gambar 10

Komponen realisasi anggaran kesehatan (milyar) dan rasio anggaran terhadap total Sumber: Kemenkes, data diolah belanja nasional tahun 2010-2017 
pelayanan kepada masyarakat dalam bidang pendidikan dan sebagai salah satu upaya untuk memenuhi amanat konstitusi bahwa alokasi anggaran pendidikan sekurangkurangnya $20 \%$ dari belanja negara. Berdasarkan Tabel 1 di atas maka diperoleh persamaan untuk belanja pendidikan sebagai berikut:

$\ln \_$bdidik $_{i t}=13,487+0,0164 \ln \_d a k_{i t}+$ $0,4111 \ln _{-} d a u_{i t}-0,073 \ln _{-} d b h_{i t}+$ $0,033 \ln _{-}$ddesa $i t+0,008 \ln _{-}$pad $_{i t}+$ $0,070 \ln _{-}$pendlainsah ${ }_{i t}+e_{i t}$

Berdasarkan Persamaan (13), peubah yang berpengaruh terhadap belanja pendidikan jika diurutkan berdasarkan yang paling tinggi nilai elastisitasnya adalah DAU, pendapatan lain yang sah, dana desa, dan DAK, sedangkan DBH tidak berpengaruh terhadap belanja pendidikan. DAU pengaruhnya cukup besar, sehingga bisa dialokasikan pada belanja pegawai kependidikan karena jumlah guru dan tenaga kependidikan lainnya di tiap daerah merupakan belanja pegawai paling besar. Dana alokasi khusus bisa saja digunakan untuk pengadaan infrastruktur pendidikan.

Pemerintah dan pemerintah daerah wajib memberikan layanan dan menjamin terselenggaranya pendidikan yang bermutu bagi setiap warga negara [UU, 2003]. Berdasarkan Gambar 10 anggaran pendidikan paling banyak tersalurkan melalui TKDD disusul belanja K/L dan terakhir melalui skema pembiayaan. Dari segi realisasi, prosentase untuk anggaran pendidikan secara umum sudah memenuhi angka 20\%, walaupun pada tahun 2011, 2012 dan 2016 target tersebut tidak tercapai. Data lengkapnya dapat dillihat pada Gambar 10 .

\section{Belanja Kesehatan}

Pembiayaan kesehatan adalah bentuk dan cara penyelenggaraan berbagai upaya penggalian, pengalokasian dan pembelanjaan dana kesehatan untuk mendukung penyelenggaraan pembangunan kesehatan guna mencapai derajat kesehatan masyarakat yang setinggi-tingginya baik berasal dari sumber pemerintah, maupun sumber lainnya yang digunakan untuk mendukung pelaksanaan pembangunan kesehatan (Dinkes Jabar 2016). Dari Tabel 1 di atas maka persamaan untuk belanja pendidikan sebagai berikut:

$$
\text { ln_bsehat } i t=3,678+0,153 \ln _{i} \text { dak }_{i t}+
$$$$
0,176 \ln _{-} \text {dau }_{i t}+0,025 \ln _{-} \text {ddesa }{ }_{i t}+
$$$$
0,406{\ln \_ \text {pad }_{i t}-0,041 \ln _{\text {_p pendlainsah }} i t}+
$$

$e_{i t}$

Berdasarkan Persamaan (14) di atas peubah yang elastisitasnya paling besar terhadap belanja kesehatan adalah PAD, DAU dan DAK. Selain pendidikan, sektor kesehatan adalah urusan wajib pemerintah yang bersentuhan sangat dekat dengan masyarakat. Pemerintah berkomitmen untuk memenuhi alokasi dana kesehatan sebesar 5\% dari total APBN, walaupun sampai tahun 2017 ternyata hal tersebut belum dapat terpenuhi.

Dari Gambar 10, persentase realisasi anggaran kesehatan sebesar 2,9\% pada tahun 2010. Tetapi trennya kemudian turun sampai tahun 2012 ke level 2,7\%, kemudian setelah itu meningkat lagi cukup tajam dan mencapai puncaknya pada tahun 2016 dimana realisasi anggarannya mencapai $4,9 \%$, walaupun pada tahun berikutnya di tahun 2017 turun kembali ke angka 4,6\%. Anggaran kesehatan masih didonimasi belanja pemerintah pusat yang besarannya mencapai lebih dari 26 triliun rupiah pada tahun 2010 dan sudah mencapai lebih dari 71 triliun rupiah pada tahun 2017. Sedangkan alokasi kesehatan melalui TKDD besarannya dari tahun 2010 sampai 2014 relatif konstan sekitar 4 triliun. Mulai tahun 2015 alokasi dana kesehatan melalui TKDD dananya meningkat pesat pada lebih dari 7,3 triliun tahun 2015, naik menjadi lebih dari 18.1 triliun tahun 2016 dan sudah mencapai lebih dari 21,3 triliun pada tahun 2017. Yang menarik dari data di bawah ternyata mulai tahun 2015 dan 2016 ada anggaran kesehatan melalui skema pembiayaan.

Pemerintah berkomitmen untuk memenuhi alokasi anggaran kesehatan sebeser $5 \%$ dari belanja negara, sebagaimana diamanatkan dalam UU No. 9 Tahun 2009 
tentang Kesehatan. Anggaran kesehatan tahun 2019 diarahkan untuk: percepatan peningkatan kepesertaan; peningkatan akses dan kualitas layanan program JKN; mendorong supply side melalui sinkronisasi pemerintah pusat dan daerah; mendorong pola hidup sehat; peningkatan nutrisi ibu hamil, menyusui dan balita, imunisasi; percepatan penurunan stunting melalui skema Program for Result (PforR); dan pemerataan akses layanan kesehatan melalui DAK Fisik dan pembangunan rumah sakit di daerah menggunakan skema Kerjasama pemerintah dan Badan Usaha atau KPBU.

\section{Belanja Ekonomi}

Belanja ekonomi bertujuan untuk mempercepat pertumbuhan ekonomi melalui pembangunan infrastruktur, transfortasi, energi, kedaulatan pangan, serta pengembangan UMKM dan kooperasi yang dapat meningkatkan pendapatan masyarakat. Persamaan untuk belanja ekonomi dapat dilihat pada persamaan di bawah:

ln_bekonomi $_{i t}=-3,253+0,050 \ln _{-}$dak $_{i t}+$ $0,8431 \ln _{-} d_{a u}+0,003 \ln _{i t} d d e s a_{i t}+$

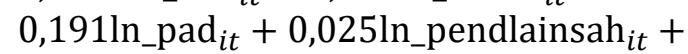
$0,286 e_{i(t-1)}$

Berdasarkan persamaan di atas peubah yang elastisitasnya paling besar terhadap belanja ekonomi secara berturut-turut adalah DAU, PAD, dan DAK.

\section{Pengaruh Belanja Daerah Terhadap Indeks Pembangunan Manusia}

Tabel 2

Regresi Peubah Terikat IPM

\begin{tabular}{lrr}
\hline \hline Peubah & Coef. & Prob. \\
\hline C & $3.7484^{* * *}$ & 0.0000 \\
ln_bmodal(-3) & $0.0064^{* * *}$ & 0.0013 \\
ln_bbjasa(-2) & $0.0121^{* * *}$ & 0.0004 \\
ln_bdidik(-3) & $0.0100^{* * *}$ & 0.0019 \\
ln_bsehat(-1) & $0.0095^{* * *}$ & 0.0015 \\
ln_bekonomi(-1) & 0.0001 & 0.9690 \\
\hline Adjusted R-squared & 0.9977 & \\
Durbin-Watson stat & 2.146 & \\
\hline
\end{tabular}

Sumber: DJPK, Kemenkeu; Data diolah
Provinsi Jawa Barat memproyeksikan pencapaian IPM 80 poin akan tercapai pada tahun 2015, tetapi terjadi perubahan menjadi tahun 2022 sesuai dengan Perda No.24 Tahun 2010 tentang perubahan Perda No. 9 Tahun 2008 tentang Rencana Pembangunan Jangka Panjang Daerah (RPJPD) Tahun 2005-2025 dan Perda No 25 Tahun 2013 tentang Rencana Pembangunan Jangka Menengah Daerah (RPJMD) Tahun 20132018 (Dinkes Jabar, 2016).

Berdasarkan dari Tabel 2 di atas maka diperoleh persamaan regresi pengaruh belanja daerah terhadap IPM sebagai berikut:

$$
\begin{aligned}
& \text { ln_ipm } \\
& =3,7484+0,0064 \ln \_ \text {bmodal }_{i(t-3)} \\
& +0,012 \ln \_ \text {bbjasa } \\
& +(t-2) \\
& +0,010 \ln _{\text {bdidik }} \quad i(t-3) \\
& +0,0095 \ln _{\text {bsehat } \quad i(t-1)} \\
& +0,0001 \ln \_ \text {bekonomi } \\
& +(t-1) \\
& +e_{i t}
\end{aligned}
$$

Berdasarkan Tabel 2, hampir semua peubah belanja perpengaruh terhadap IPM, hanya peubah belanja ekonomi yang tidak berpengaruh signifikan terhadap IPM. Belanja pemerintah daerah di Jawa Barat yang elastisitasnya paling tinggi secara berurutan adalah: belanja barang dan jasa, belanja pendidikan, belanja kesehatan dan belanja modal. Ini artinya ada keterkaitan antara belanja pendidikan dan kesehatan dengan peningkatan IPM (Sasana H. 2012; Dissou et al., 2016; Asaju dan Kayode, 2012; Gupta dan Clements, 1998) Ini sangat logis mengingat varibel berbentuk skor IPM terdiri dari kesehatan, pendidikan dan ekonomi, belanja kesehatan berpengaruh terhadap IPM (Bhakti et al. 2012).

Belanja modal bisa digunakan untuk membangun sarana pendidikan seperti sekolah, rumah sakit, puskesmas, sarana transfortasi seperti jalan yang pada akhirnya akan berdampak pada kulitas pendidikan, kesehatan dan perekonomian masyarakat. Sehingga belanja modal akan berpengaruh terhadap IPM (Setiawan dan Budiana, 2015; Setiawan dan Budiana, 2015; Tarumingkeng 
et al., 2018; Mirza DS, 2012). Belanja pendidikan bisa dipergunakan untuk biaya operasional sekolah (BOS), beasiswa pendidikan, perbaikan infrastruktur sarana dan prasarana sekolah, belanja pegawai dan yang lainnya. Dengan adanya BOS biaya individu untuk pendidikan menjadi lebih murah demikian juga beasiswa, sehingga akan meningkatkan harapan lama sekolah dan rata-rata lama sekolah yang berdampak pada peningkatan skor IPM.

\section{Pengaruh Total}

Pengaruh satu variabel terhadap variabel lainnya bisa langsung tetapi bisa juga melalui variabel lain (mediasi). Pengaruh DAK terhadap IPM bisa melalui beberapa jalur, antara lain: ln_dak $\rightarrow \ln \_$bmodal $\rightarrow$ ln_ipm; ln_dak $\rightarrow$ ln_bbjasa $\rightarrow \operatorname{ln\_ ipm~dan~}$ yang lainnya.

Tabel 3

Pengaruh Total

\begin{tabular}{lr}
\hline \hline Jalur & Koefisien \\
\hline ln_dak $\rightarrow$ ln_ipm & 0.002652 \\
ln_dau $\rightarrow$ ln_ipm & 0.018011 \\
ln_dbh $\rightarrow$ ln_ipm & 0.000096 \\
ln_ddesa $\rightarrow$ ln_ipm & 0.000758 \\
ln_pad $\rightarrow$ ln_ipm & 0.010083 \\
ln_pendlainsah $\rightarrow$ ln_ipm & 0.002577 \\
\hline
\end{tabular}

Sumber: DJPK, Kemenkeu; Data diolah

Pengaruh total adalah penjumlahan dari berbagai jalur mediasi, pengaruh total dari dana transfer dan PAD terhadap IPM dapat dilihat pada Tabel 3. Berdasarkan tabel tersebut, yang pengaruhnya paling tinggi terhadap IPM secara berurutan adalah DAU $(0,018011)$, PAD $(0,010083)$ dan DAK $(0,002652)$.

\section{Diskusi dan Pembahasan}

IPM merupakan gambaran yang cukup baik dalam menyatakan seberapa besar penduduk di suatu wilayah dapat mengakses hasil dari pembangunan, walaupun indeks ini masih mendapatkan berbagai kritik (Surajit, 2015; Fukuda, 2003). IPM menunjukkan pencapaian dalam standar hidup suatu populasi dalam hal tingkat pencapaian atribut kualitas hidup yang berbeda, seperti pencapaian pendidikan dan harapan hidup saat lahir (Chakravarty, 2003). IPM telah mengalami modifikasi substansial pada tahun 2010 beberapa variabel, prosedur agregasi mengalami perubahan (Herrero et al. 2012),

Peningkatan kualitas SDM, seharusnya tidak hanya sematamata tertuju pada aspek jasmaniah melainkan juga pada aspek rohaniah (Herwanti dan Irwan 2013). Indeks ini sudah diakui secara internasional, bahkan UNDP selalu mengeluarkan IPM ini secara berkala. IPM merupakan rataan geometrik yang berasal dari 3 indikator yaitu: kesehatan; pendidikan dan hidup layak.

Pendapatan daerah yang meliputi PAD dan dana perimbangan yaitu DAU, DAK dan DBH berpengaruh terhadap IPM (Harahap, 2011). Peubah yang pengaruhnya paling besar terhadap IPM (dillihat berdasarkan nilai elastisitas totalnya) adalah Dana Alokasi Umum dan Pendapatan Asli Daerah. DAU (setelah dikeluarkan untuk gaji pegawai dan Alokasi Dana Desa) dan PAD merupakan pendapatan daerah yang pengalokasiannya, pemerintahan daerah relatif mempunyai kebebasan. Untuk itu pemerintah daerah harus bisa mengalokasikan belanja yang bersifat produktif sehingga dapat berdampak pada kesejahteraan rakyat. Pemerintah daerah juga harus terus menggali potensi daerah tanpa membebani masyarakat, tetapi membuka peluang usaha yang berbasiskan ekonomi daerah untuk bisa meningkatkan PAD.

Pemerintah telah mengadopsi penghitungan IPM metode baru yang dikeluarkan oleh UNDP. Jika dalam metode lama skor IPM diperoleh dari rata-rata aritmatika maka dalam metode baru penghitungannya menggunakan rata-rata geometri. Dalam metode lama jika ada satu variabel IPM yang rendah bisa ditutupi oleh variabel yang lain sehingga hasilnya tetap tinggi. Karena dalam 
metode baru, skor IPM diperoleh dari akar pangkat tiga hasil perkalian antar tiga variabel penyusun IPM, maka skor IPM yang tinggi akan diperoleh jika semua komponen memperoleh skor yang tinggi. Skor tidak akan tinggi jika ada satu variabel yang nilainya rendah. Untuk meningkatkan sumberdaya manusia di suatu wilayah harus komprehensif tidak cukup kalau yang maju satu sektor saja, harus berbarengan.

Berdasarkan Tabel 2, belanja pendidikan berpengaruh terhadap IPM (Ala HM, 2015). Pengaruh dari belanja terhadap IPM tidak seperti pengaruh dari pendapatan daerah terhadap belanja. Pengaruh dari belanja terhadap IPM mempunyai lag, artinya pengaruhnya dari belanja terhadap IPM tidak dapat dirasakan dampaknya pada tahun itu juga. Pengaruh belanja terhadap IPM baru akan terasa setelah berlalu beberapa tahun, misalkan pengaruh belanja pendidikan dan belanja modal baru akan dirasakan setelah berlaku tiga tahun. Jika belanja pendidikan diberikan saat anak kelas 1 SMP maka baru terlihat dampaknya ketika anak tersebut sudah kelas 1 SMA. Demikian juga dengan belanja yang lainnya. Hal ini berdampak pada evaluasi terhadap belanja yang dilakukan, karena tidak seperti membuat infrastruktur yang hasilnya berupa jalan, gedung, pasar, atau yang lainnya, dimana hasilnya bisa dipantau setiap saat. Di sisi lain, karena dampak dari belanja terhadap IPM baru bisa dirasakan dalam jangka panjang, maka dalam melakukan belanja daerah harus betul-betul dilakukan berdasarkan pertimbangan yang matang, agar berdampak pada perbaikan sumberdaya manusia di wilayah tersebut. Jangan terlalu tergesa-gesa dalam melakukan kesimpulan (gagal atau berhasil) dari suatu program yang dampaknya baru bisa dirasakan dalam jangka lama.

\section{SIMPULAN DAN SARAN Simpulan}

Berdasarkan pembahasan di atas dana transfer (DAU, DBH, DAK dan Pendapatan lain yang sah), PAD dan Dana Desa berpengaruh terhadap indeks pembangunan manusia. Pendapatan daerah yang paling berpengaruh terhadap IPM secara berurutan adalah Dana Alokasi Umum, Pendapatan Asli Daerah atau PAD dan Dana Alokasi Khusus atau DAK. Hal ini bisa dilihat dari nilai elastisitas atau pengaruh total masingmasing pendapatan daerah.

\section{Saran}

Supaya belanja yang dilakukan oleh pemerintah daerah memberikan dampak yang signifikan, maka kualitas belanja harus diperhatikan. Belanja harus digunakan untuk kegiatan yang produktif, efisien, tepat sasaran, akuntabel, transparan, dan mampu menciptakan lapangan kerja baru sehingga mampu mengurangi pengangguran, bisa mengurangi ketimpangan. Metode baru penghitungan Indeks Pembangunan Manusia diperoleh dari rata-rata geometris, sehingga skor IPM yang tinggi hanya bisa diperoleh jika ketiga komponen penyusun IPM bernilai tinggi. Peningkatan SDM suatu wilayah akan berhasil jika semua sektor dibangun, pemerintah daerah harus mampu membuat program yang bisa meningkatkan SDM di wilayahnya. Harus ada kerjasama dan komunikasi antar berbagai sektor, kesehatan, pendidikan dan pemangku kebijakan lainnya agar semua komponen samasama berkembang. Sumberdaya manusia yang unggul akan membawa kemajuan bagi suatu wilayah, karena komponen SDM merupakan subjek bukan objek pembangunan, sehingga SDM merupakan unsur yang paling penting dalam pembangunan.

Berdasarkan analisis sebelumnya dampak dari belanja tehadap IPM tidak akan dirasakan pada saat itu juga, tetapi dampaknya baru dapat dirasakan setelah berlalu jangka waktu tertentu. Evaluasi terhadap kinerja IPM pengaruh dari belanja daerah tidak bisa dilakukan dalam waktu dekat, tetapi bisa jadi setelah tiga tahun, empat tahun atau bisa jadi setelah rejim yang melakukan program tersebut berganti. Karena itu ketika akan membuat progran yang berdampak dalam jangka panjang 
harus dilakukan secara cermat dan berkualitas.

Indeks Pembangunan Manusia atau IPM bisa dijadikan patokan untuk mengukur kinerja pembangunan wilayah karena mencakup indikaor yang penting yaitu pendidikan, kesehatan dan kesejahteraan masyarakat. Berdasarkan penelitian ini ternyata belanja pendidikan (Ratnasari et al. 2019; Astri et al. 2013) dan kesehatan berpengaruh terhadap IPM.

\section{DAFTAR PUSTAKA}

Anand, S. dan A. Sen. 2000. The Income Component of the Human Development Index. Journal of Human Development and Capabilities (1)1: 83-106.

Ala, H. M. 2015. Pengaruh Belanja Langsung Sektor Pendidikan, Kesehatan, Infrastruktur, dan Pertanian Terhadap IPM (Studi Kasus pada Kabupaten atau Kota Provinsi NTT). Wahana: Jurnal Ekonomi, Manajemen, dan Akuntansi 18(2): 163-174.

Alwi, W., I. Rayyan, dan K. Nurfadilahi. 2019. Analisis Regresi Data Panel pada Faktor-Faktor yang Mempengaruhi Tingkat Kemiskinan Provinsi Sulawesi Selatan Tahun 2011-2015. Jurnal MSA (Matematika dan Statistika serta Aplikasinya 6(2): 30-44.

Asaju, K. 2012. Human Capital Development and Poverty Alleviation in Ingeria: a Symbiotic Overview. Wukari: Federal University Wukari.

Arwaty, D. dan N. Hadiati. 2013. Pengaruh Pertumbuhan Ekonomi, Pendapatan Asli Daerah dan Dana Alokasi Umum terhadap Pengalokasian Anggaran Belanja Modal pada Pemerintah Daerah Kabupaten atau Kota di Provinsi Jawa Barat. Seminar Nasional Teknologi Informasi dan Komunikasi Terapan 2013. Semarang: 498-507.

Astri, M., S. I. Nikensari, dan H. Kuncara. 2013. Pengaruh Pengeluaran Pemerintah Daerah pada Sektor Pendidikan dan Kesehatan Terhadap Indeks Pembangunan Manusia di Indonesia. Jurnal
Pendidikan Ekonomi Dan Bisnis (JPEB) 1(1): 77-102.

Brojonegoro B. 2019. Bappenas: Belanja K/L Belum Optimal Dorong Ekonomi. https://ekonomi.bisnis.com/read/20190812/ 9/1135411/bappenas-belanja-kl-belumoptimal-dorong-ekonomi. Diakses tanggal 04 Maret 2020.

Bhakti, N. A., I. Istiqomah, dan S. Suprapto. 2014. Analisis Faktor-Faktor yang Mempengaruhi Indeks Pembangunan Manusia di Indonesia Periode 20082012. Ekuitas: Jurnal Ekonomi dan Keuangan 18(4): 452-469.

Chakravarty, S. R. 2003. A Generalized Human Development Index. Journal Review of Development Economics 7(1): 99114.

Dinas Kesehatan Provinsi Jawa Barat. 2016. Profil Kesehatan Provinsi Jawa Barat Tahun 2016. Dinas Kesehatan Provinsi Jawa Barat.

Dissou, Y., S. Didic, dan T. Yakautsava. 2016. Government Spending on Education, Human Capital Accumulation, and Growth. Economic Modeling 58(2016): 921.

Fukuda-Parr, S. 2003. The Human Development Paradigm: Operationalizing Sen's Ideas on Capabilities. Feminist Economics 9(2-3): 301-317.

Gupta, S. dan B. Clement. 1998. Public Spending on Human Development. Finance E Development 35(3): 10-13.

Harahap, R. U. 2011. Pengaruh Dana Alokasi Umum, Dana Alokasi Khusus dan Dana Bagi Hasil Terhadap Indeks Pembangunan Manusia pada Kab. Atau Kota Provinsi Sumatra Utara. Jurnal Riset Akuntasi dan Bisnis 11(1): 47-58.

Haryanto, S. 2013. Analisis Pengaruh PAD, DAU dan DAK Terhadap Belanja Modal dan Belanja Barang dan Jasa Kota dan Kabupaten di Provinsi Jawa Timur Tahun 2006-2012. Jurnal Ekonomi Modernisasi 9(2): 140-160.

Hasan, M. 2015. Pengaruh Dana Transfer Pusat Terhadap Pertumbuhan Ekonomi Daerah Kabupaten atau Kota di 
Sulawesi Selatan. Jurnal Economix 3(1): 13-21.

Herrero, C., R. Martinez, dan A. Villar. 2012. A Newer Human Development Index. Journal of Human Development and Capabilities 13(2): 247-268.

Herwanti, T. dan M. Irwan. 2013. Kualitas Sumber Daya Manusia dalam Perspektif Ekonomi Islam di Nusa Tenggara Barat. Ekuitas: Jurnal Ekonomi dan Keuangan 17(2): 131-154.

Hidayat, I., R. Rosidi, dan E. Saraswati. 2012. Pengaruh Belanja Pendidikan Terhadap Kinerja Pendidikan dengan Good Governance sebagai Variabel Moderasi. Jurnal Akuntansi Multiparadigma 3(2): 173-186.

Juanda B. 2009. Ekonometrika: Permodelan dan Pendugaan. IPB Press. Bogor (ID).

Juanda, B., E. Suratman, dan H. Handra. 2017. The Fiscal Transfer Effect on Regional Inequality. The $6^{\text {th }}$ Indonesian Regional Science Association (IRSA) International Institute, Manado, 17-18 Juli 2017.

Kahang, M., M. Saleh, dan R. B. Suharto. 2016. Pengaruh Pengeluaran Pemerintah Sektor Pendidikan dan Kesehatan Terhadap Indeks Pembangunan Manusia di Kabupaten Kutai Timur. Jurnal Ekonomi, Manajemen dan Akuntansi 18(2): 130-140.

Kis-Katos, K. dan B. S. Sjahrir. 2017. The Impact of Fiscal and Political Decentralization on Local Public Investment in Indonesia. Journal of Comparative Economics 45(2): 344-365.

Litvack, J. dan J. Seddon. 1999. Decentralization Briefing Notes. World Bank Institute (WBI) Working Papers. Washington DC.

Mankiw, N. G. 2006. Principles of Microeconomics. Fourth Edition. Thomson Higher Education. Mason, USA.

Mawarni, D. dan S. Abdullah. 2013. Pengaruh Pendapatan Asli Daerah dan Dana Alokasi Umum terhadap Belanja Modal serta Dampaknya terhadap Pertumbuhan Ekonomi Daerah. Jurnal
Akuntansi Pascasarjana Universitas Syah Kuala 2(2): 80-90.

Meutuah, S. M., H. Yasin, I. M. Di Asih. 2017. Pemodelan Fixed Effect Geographically Weighted Panel Regression untuk Indeks Pembangunan Manusia di Jawa Tengah. Jurnal Gaussian 6(2): 241-250.

Mirza, D. S. 2012. Pengaruh Kemiskinan Pertumbuhan Ekonomi dan Belanja Modal Terhadap Indeks Pembangunan Manusia di Jawa Tengah Tahun 20062009. Economics Development Analysis Journal 1(1): 1-15.

Musgrave, R. 1969. Cost Benefit Analysis and the Theory of Public Finance. Journal of Economic Literature 7: 797-806.

Oates, W. E. 1999. An Essay on Fiscal Federalism. Journal of Economic Literature 37(3): 1120-1149.

Pelealu, A. M. 2013. Pengaruh Dana Alokasi Khusus (DAK) dan Pendapatan Asli Daerah (PAD) Terhadap Belanja Modal Pemerintah Kota Manado Tahun 20032012. Jurnal EMBA 1(4): 1189-1197.

Peraturan Menteri Keuangan Republik Indonesia No. 127/PMK.02/2015 tentang Klasifikasi Anggaran.

Peraturan Menteri Keuangan Republik Indonesia No. 50/PMK.07/2017 tentang Pengelolaan Transfer ke Daerah dan Dana Desa.

Rajkumar, A. S. dan V. Swaroop. 2008. Public Spending and Outcomes: Does Governance Matter?. Journal of Development Economics 86(1): 91-111.

Ratnasari, G. T., S. Wibisono, dan A. Hanim. 2019. Analisis Faktor-Faktor Yang Mempengaruhi Indeks Pembangunan Manusia di Wilayah Eks Karesidenan Besuki. Jurnal Ekuilibrium 3(2): 45-53.

Romer, D. 2006. Advanced Macroeconomics. Third Edition. McGraw-Hill Irwing. New York (US).

Samuelson, P. A. 1958. Aspects of Public Expenditure Theories. The Review of Economics and Statistics 40(4): 332-338.

Sasana, H. 2012. Pengaruh Belanja Pemerintah Daerah dan Pendapatan Perkapita Terhadap Indeks Pembangunan 
Manusia (Studi Kasus di Kabupaten atau Kota Provinsi Jawa Tengah). Media Ekonomi dan Manajemen 25(1): 1-12.

Setiawan, G. B. K. P. dan D. N. Budiana. 2015. Pengaruh Belanja Modal Terhadap Indeks Pembangunan Manusia Melalui Pertumbuhan Ekonomi Sebagai Variabel Intervening Provinsi Bali. E-Jurnal Ekonomi Pembangunan Universitas Udayana 4(10): 1276-1303.

Setiawan, M. I. 2018. Evaluasi Penggunaan Dana Transfer Khusus Bidang Kesehatan dan Penyediaan Pelayanan Kesehatan. Jurnal Defis 3(3): 21-29.

Shah A. 1991. The New Fiscal Federalism in Brazil. World Bank Discussion Papers WDP 124. World Bank Group. Washington DC.

Shah A. 2007. A Practitioner's Guide to Intergovernmental Fiscal Transfers. Policy Research Working Paper Series 4039: 1-53. The World Bank.

Surajit, D. 2015. The Human Development Index and Its Methodological Refinements. Jounals Sagepub 45(1): 131-136.

Suryana. 2018. Pengaruh Pendapatan Asli Daerah (PAD), Dana Alokasi Umum (DAU), Dana Alokasi Khusus (DAK) Terhadap Belanja Modal. Jurnal Ilmu Manajemen $\mathcal{E}$ Bisnis 9(2): 67-73.
Suryani, F. dan E. Pariani. 2018. Pengaruh Pendapatan Asli Daerah dan Dana Alokasi Umum Terhadap Belanja Modal Pada Kabupaten atau Kota di Provinsi Riau. Jurnal Pendidikan Ekonomi Akuntansi 6(1): 11-22.

Tarumingkeng, W. A., V. A. Rumate, dan T. O. Rotinsulu. 2018. Pengaruh Belanja Modal dan Tingkat Kemiskinan Terhadap Indeks Pembangunan Manusia. Jurnal Pembanguan Ekonomi dan Keuangan Daerah. Jurnal Pembangunan Ekonomi dan Keuangan Daerah 19(6): 1-14.

Todaro, M. P. 2000. Pembangunan Ekonomi di Dunia Ketiga. Edisi Ketujuh. Penerbit Erlangga. Jakarta.

UNDP. 2019. Human Development Report 2019, Beyond Income, Beyond Averages, Beyond Today: Inequalities in Human Development in the 21st century. United Nations Development Programme (UNDP). New York, USA.

Undang-Undang No. 23 tahun 2014 tentang Pemerintah Daerah.

Wandira, A. G. 2013. Pengaruh PAD, DAU, DAK, dan DBH Terhadap Pengalokasian Belanja Modal. Accounting Analysis Journal 2(1): 44-49. 